\title{
MedienPädagogik
}

Zeitschrift für Theorie und Praxis der Medienbildung

Media-related Educational Competencies of German and US Preservice Teachers. A Comparative Analysis of Competency Models, Measurements and Practices of Advancement

\section{Part III: Advancing Media-related Educational Competencies}

Jennifer Tiede

In the first part of this dissertation, selected models and standards from Germany and the USA were introduced, based on a literature review and thus revealing what is considered relevant for practice in a variety of sources and which competencies preservice teachers should acquire, according to these sources. In the second part, methods and selected results of competency measurements were introduced, thus demonstrating ways to operationalize the models and to assess the outcomes of respective processes of such a model integration. Complementary to these theoretical and measurement-focused perspectives on mediarelated educational competencies, it is important to extend the viewpoint to practices of media-related education of preservice teachers: the objectives both of competency models and of competency measurements ultimately include impacting the respective practices in teacher education and offering a grounded basis and stimuli for improvements and enhanced practice. In accordance with this, various sources emphasize the importance of research on the integration of ICT and respective competencies into initial teacher education (Enochsson and Rizza 2009; Krumsvik 2014; Tondeur et al. 2017).

Hence, in the light of the previous two parts, it is now consistent to explore how far the theoretical basics and measurements, with their results, find their way into actual practice. Naturally, there are factors impacting current practices beyond research and measurements, even though a majority of the respective literature tends to focus on specific competencies and to neglect the influence of broader contextual conditions (Pettersson 2018). To acknowledge this desideratum, the following question will be explored: "How are mediarelated educational competencies advanced in German and US American study programs of teacher education?" This question will guide the focus of the following chapter to shed light on current practices and trends in German and US practice of teacher education in the context of advancing media-related educational competencies comprehensively, first from a theory-based and then from an empirical perspective. Thus, it will be illustrated first how media-related educational competencies are integrated into initial teacher education programs, and central stakeholders will be outlined systematically to identify the network of influences responsible for the ways in which competencies are advanced in initial teacher education. Afterward, a study will be introduced that sought to further explore these practices and influences by expert interviews, which are also the subject of Paper 2, "The Integration of Media-Related Studies and Competencies into US and German Initial Teacher Education. A Cross-National Analysis of Contemporary Practices and Trends," that will be included subsequently to complete the comprehensive analysis of practices of advancing media-related educational competencies in initial teacher education in Germany and the USA.

Tiede, Jennifer. 2020. «Part III: Advancing Media-related Educational Competencies». MedienPädagogik, (Media-related Educational Competencies), 152-220. https://doi.org/10.21240/mpaed/diss.jt/2020.07.03.X 


\section{Current Practices in the Advancement of Media-related Educational Compe-} tencies in Germany and the US: Empirical Evidence

Generally, there are different options for integrating models and respective efforts of competency advancement into teacher education. Integration can basically happen either obligatorily (all students within a certain target group have to take respective courses), or voluntarily (there are offers which students can opt to take). According to Oliver and Townsend (2013), formats include preservice training, long-term courses, short-term workshops and institutes, coaching/mentoring, learning communities, and product/assessment approaches. The applicability or reference frame of respective regulations can vary from local, e.g., binding for specific cohorts of students at a university, to state-wide or even national.

\subsection{Germany}

Considering the German situation, there are numerous references in research, political documents and further sources pointing out the deficiency of the integration of respective contents into initial teacher education. Already in 2003, Blömeke stated that teachers are not adequately prepared with regards to media pedagogy because the respective qualification was only integrated into professional development, if at all. She concluded that the integration of these contents into initial teacher education has been marginal to this point (cf. also Tulodziecki and Herzig 2002; Spanhel 2001) but described a current shift in public perception (Blömeke 2003). This shift, however, seemed not to lead to systematic improvements everywhere. Kammerl and Mayrberger (2011) summarize the situation of the integration of media-related educational competencies into German initial teacher education from the perspectives of structural and educational policy and empiricism. The authors still conclude that the systematic advancement of media-related educational competencies in German teacher education is scarce and that the development and advancement of respective competencies is hardly noticed in research on teacher education. Hence, the theoretical foundation and empirical research on media pedagogical professionality as an objective of teacher education and as a professional characteristic of teachers is called a research desideratum.

In more recent sources, there is evidence of an ongoing heterogeneous integration, but binding regulations on different levels are increasingly being mentioned. For example, Aufenanger (2014) describes the example of Rhineland-Palatine as one of a few states which have obligatory study contents with reference to media pedagogy. Niesyto (2014) mentions the Pädagogische Hochschule Ludwigsburg as the first German institution of higher education to make introductory courses about media pedagogy obligatory for all preservice teachers. Overall, several sources from different backgrounds demand for a systematic and obligatory integration into initial teacher 
education for every German preservice teacher (e.g., Spanhel 2001; Tulodziecki and Herzig 2002; Blömeke 2003; Kammerl and Mayrberger 2011; Imort and Niesyto 2014; Schmid et al. 2017; Kultusministerkonferenz [KMK] 2016; Bundesministerium für Forschung und Bildung [BMBF] 2016; van Ackeren et al. 2019).

Related literature also introduces a number of relevant studies in this context. To learn more about the structural and formal integration of media-related studies into German teacher education, Schiefner-Rohs (2012) presents a review of 90 documents primarily from three universities as examples; they include examination regulations, study guidelines, course catalogs, and standards. The references to medienpädagogische Kompetenz identified are structured in accordance with the competency aspects suggested by Blömeke (2000; cf. Chapter 4.3), i.e., media didactical competence, media educational competence, socialization-related competence in media contexts, school reform competence in media contexts, and own media competence. Against the background of methodological limitations, especially with regards to the concentration on document analyses only, the author concludes that the formal integration of medienpädagogische Kompetenzen into documents of teacher education on federal and university levels is deficient, scarce and considerably heterogeneous with regards to references to the five competency aspects and to extent and frequency. However, she also emphasizes that such an integration into respective documents does not allow for conclusions on how media-related educational competencies are actually addressed and realized in practice, because it only illustrates the formal relevance. To meet this critique, she recommends enhancing her study by further methods, such as lesson observations or interviews (Schiefner-Rohs 2012) - a claim that will be responded to in Chapter 11 .

A recent study in this context was also conducted by Bertelsmann Stiftung et al. (2018). In the project Monitor Lehrerbildung [monitor for teacher education], German states and institutions of higher education were surveyed on the ways in which respective study offerings are integrated into curricula of initial teacher education. With regards to the acquisition of media-related educational competencies, the two main categories analyzed in this study are handling digital media and the methodological-didactic implementation of digital media in school. In terms of the classification of media-related educational competencies suggested in Chapter 5.1.3, "handling digital media" refers to "teachers' own technological knowledge and ICT competencies" while "the methodological-didactic implementation of digital media in school" can be assigned to the category of "using media and ICT to enhance educational processes." The survey results with regards to respective study offerings are summarized in Table 13. 


\begin{tabular}{|c|c|c|c|c|c|c|c|}
\hline \multirow{2}{*}{$\begin{array}{l}\text { Obligatory } \\
\text { courses in ITE } \\
\text { curriculum for } \\
\text { the acquisition } \\
\text { of professional } \\
\text { competencies } \\
\text { for ... }\end{array}$} & \multirow[t]{2}{*}{ School form } & 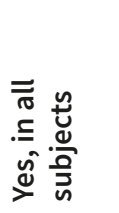 & 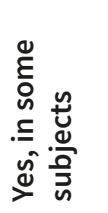 & 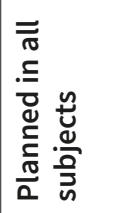 & 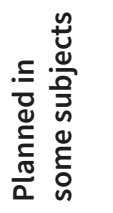 & 운 & $\stackrel{\pi}{\Omega}$ \\
\hline & & $\begin{array}{l}\mathrm{n} \text { insti- } \\
\text { tutions } \\
\text { of } \mathrm{HE}\end{array}$ & $\begin{array}{l}n \text { insti- } \\
\text { tutions } \\
\text { of } \mathrm{HE}\end{array}$ & $\begin{array}{l}\text { n insti- } \\
\text { tutions } \\
\text { of } \mathrm{HE}\end{array}$ & $\begin{array}{l}n \text { insti- } \\
\text { tutions } \\
\text { of } \mathrm{HE}\end{array}$ & $\begin{array}{l}n \text { insti- } \\
\text { tutions } \\
\text { of } \mathrm{HE}\end{array}$ & $\begin{array}{l}n \text { insti- } \\
\text { tutions } \\
\text { of } \mathrm{HE}\end{array}$ \\
\hline \multirow[t]{3}{*}{$\begin{array}{l}\text {... handling } \\
\text { digital media }\end{array}$} & $\begin{array}{l}\text { ITE for Elemen- } \\
\text { tary school ( } \mathrm{n} \\
=45 \text { ) }\end{array}$ & 5 & 21 & 1 & 2 & 8 & 8 \\
\hline & $\begin{array}{l}\text { ITE for Second- } \\
\text { ary school, } \\
\text { level I }(n=49)\end{array}$ & 6 & 22 & 1 & 3 & 10 & 7 \\
\hline & $\begin{array}{l}\text { ITE for Second- } \\
\text { ary school, } \\
\text { level II (general } \\
\text { education) (n } \\
=60 \text { ) }\end{array}$ & 7 & 24 & 1 & 4 & 13 & 11 \\
\hline \multirow{3}{*}{$\begin{array}{l}\text {... the meth- } \\
\text { odological- } \\
\text { didactic imple- } \\
\text { mentation of } \\
\text { digital media } \\
\text { in school }\end{array}$} & $\begin{array}{l}\text { ITE for Elemen- } \\
\text { tary school ( } \mathrm{n} \\
=45 \text { ) }\end{array}$ & 2 & 23 & 1 & 3 & 8 & 8 \\
\hline & $\begin{array}{l}\text { ITE for Second- } \\
\text { ary school, } \\
\text { level I }(n=49)\end{array}$ & 4 & 23 & 1 & 4 & 10 & 7 \\
\hline & $\begin{array}{l}\text { ITE for Second- } \\
\text { ary school, } \\
\text { level II (general } \\
\text { education) ( } \mathrm{n} \\
=60 \text { ) }\end{array}$ & 7 & 24 & 1 & 6 & 11 & 11 \\
\hline
\end{tabular}

Tab. 13.: Obligatory courses with relation to media-related educational competencies in curricula at the institutional level (Bertelsmann Stiftung et al., 2018).

A first observation from the data presented in Table 13 is that, both in the case of the acquisition of own digital media competence and in the case of the acquisition of competencies in teaching with media, more than $50 \%$ of the institutions of higher education in the study indicated having installed respective obligatory study offers in their curricula of initial teacher education for all school forms listed here. However, the predominant format is an inclusion in some subjects. Hence, a potential conclusion is that the combination of subjects a preservice teacher selects can have an influence on his or her exposure to courses advancing media-related educational competencies.

Overall, the data from Monitor Lehrerbildung indicate that an integration of media-related content into all subjects and disciplines in all 16 German states has not 
yet been achieved. On the state level, in a majority of states there are no binding regulations for the advancement of professional competencies in the handling of media and in their methodological and pedagogical integration into school (cf. Chapter 10.2). A core conclusion of the study is that overall there is not enough obligation for German preservice teachers to deal with digital media in their studies. In many places, they can still graduate without ever having to take courses on this topic, and even voluntary offerings are not guaranteed in all places.

Naturally, obligatory course offerings as assessed by Monitor Lehrerbildung are not the only way for institutions of higher education to integrate respective contents into their curricula. The collection of data focused solely on obligatory study offerings neglects further developments and efforts in terms of elective study offers. Other ways of structurally establishing elective study offers are described by various further sources from practices in German institutions of teacher education. Specifically, such ways include elective courses within regular programs of teacher education, extended or supplementary studies, and study foci and study emphases.

Elective courses within regular initial teacher education curricula are courses preservice teachers can opt to take from a range of suggested courses. Opportunities for making own selections were reduced in the course of the Bologna reforms in the German system of higher education (cf. Kotthoff and Terhart 2013, for an overview of the effects of the Bologna reforms on the German system of teacher education). Yet a certain flexibility still allows students at some places to actively decide for media pedagogical courses according to their own interests. Some institutions of initial teacher education also offer extended or supplementary studies in the field of interest. These courses are taken on top of the regular coursework (Niesyto 2014; Goertz and Baeßler 2018). Finally, there are also institutions offering preservice teachers to define a focus or study emphasis on media pedagogy, which means taking a range of respective classes in their regular teacher education program (Herzig, Aßmann, and Klar 2014). Sometimes, such study foci are also combined with an additional certificate to be achieved (Kammerl and Mayrberger 2014).

It can be concluded from these sources that there is an established awareness of the need for advancing media-related educational competencies in teacher education, and various efforts show approaches to a successful integration of respective contents. Yet, the current status quo in German teacher education has been and is still being characterized largely by heterogeneity and inconsistency.

\subsection{USA}

As has been pointed out before, the need for advancing the media-related educational competencies of preservice teachers has also been seen in the USA (cf., for example, American Association of Colleges of Teacher Education [AACTE] and Partnership 
for 21st Century Skills [P21] 2010; Hobbs 2010; International Society for Teaching in Education [ISTE] 2017; U.S. Department of Education, Office of Educational Technology 2016; 2017). An early study in the US context has been published by Milken Exchange on Education Technology (1999) to gather information on the IT preparation that preservice teachers receive. Key outcomes of this study include a technology infrastructure widely perceived as adequate but offering little integration of IT skills into teacher education. According to the study, most teacher preparation programs in the US in the late 1990s did not have a "written, funded, regularly-updated technology plan" (p. 9), which implies that respective study experiences for preservice teachers were rather unsystematic at this early stage.

Less than ten years later, Kleiner, Thomas, Lewis and Greene (2007) published a new national study on the integration of educational technology into US teacher education programs, based on a survey with nearly all US Title IV degree-granting 4-year institutions of teacher education. All the institutions in this sample reported integrating technology into instruction and teaching about the use of internet resources and communication tools for instruction in all or some of their teacher education programs. Additionally, "the majority of institutions offering teacher education programs for initial licensure reported that they had prepared their teacher candidates (to a moderate or major extent) to use educational technology for a variety of purposes [...]" (ibid., p. 17).

With regards to the integration of these contents into teacher education programs, the study finds that about half of the institutions offer stand-alone courses in educational technology and many of them also integrate educational technology within methods courses (93\%), within field experiences (79\%), and within content courses $(71 \%)$. An interesting conclusion in this context refers to the low variation by institutional and program characteristics between the institutions, which indicates "a fairly common approach to educational technology across the nation's teacher education programs for initial licensure" (ibid., p. 17). This seems surprising against the background of the heterogeneous findings from Milken Exchange on Education Technology (1999) and shows the progress and increase of importance of technology in teacher education in the early 2000s. However, the statistical analyses neither inform about causal relations nor offer conclusions regarding quality and outcomes, focusing instead on the course and content offerings.

Further related empirical evidence has been presented by Gronseth et al. (2010). A survey was sent out to all 1,283 four-year teacher education programs in the US offering an initial teaching licensure in general, elementary, and/or secondary education received $n=407$ responses. Major outcomes of this study include the notion that $60 \%$ of the institutions had a required standalone educational technology course in all teacher licensure programs, and an additional $20 \%$ had such a required course in some teacher programs. The share of institutions requiring technology-related projects or activities in teaching methods courses was at $44 \%$. 
Despite this seemingly comprehensive integration of ICT into teacher education, US researchers have been pointing out repeatedly that teachers do often not effectively use media and ICT in their teaching and that the advancement of media-related educational competencies is far from satisfying (Belland 2009; Ertmer and Ottenbreit-Leftwich 2010; Sang et al. 2010; U.S. Department of Education, Office of Educational Technology 2017; Riegel and Tong 2017). A frequently discussed topic in US research in this context is the question of how to best integrate the respective contents, and there has been a considerable consensus recently to foster an inclusive approach and to infuse media and ICT-related teacher education into subject courses and contents as opposed to standalone courses on educational technology, which could then be abolished (Polly et al. 2010; Hur, Cullen, and Brush 2010; Slepkov 2013; Bakir 2016; Foulger et al. 2017; Foulger, Wetzel, and Buss 2019).

Notably, these studies on the integration of ICT into teacher education and respective considerations on an optimized integration into teacher education programs tend to focus on the educational technology perspective, i.e., on those competency aspects related to teaching with media or the pedagogical use of media and ICT. The perspective of media literacy offers a different picture: in 2016, Redmond called it "unclear if or how MLE [media literacy education] is included in teacher education programs and training" $(2016,33)$, and Gretter and Yadav point out a "lack of teacher preparation in teaching media and information literacy skills" $(2018,104)$, although the need for such an education has been realized widely (Center for Media Literacy [CML] n.d.; Torres and Mercado 2006). Redmond (2016) summarizes five studies in this context which all lead to the conclusion that media literacy is important in teacher education but deficiently integrated (Schwarz 2001; Goetze, Brown, and Schwarz 2005; Flores-Koulish 2006; Flores-Koulish and Deal 2008; Flores-Koulish et al. 2011). Single recent sources claim an improvement of this matter, with the notion that media literacy could - and should - be integrated into the rest of the curriculum, as opposed to standalone courses, just like educational technology (Meehan et al. 2015). This claim corresponds to the technology infusion approach described above in the context of educational technology.

\subsection{Germany and the USA: Comparative Conclusions}

Comparative sources on current practices of the advancement of media-related educational competencies in German and US teacher education are scarce. Tiede, Grafe and Hobbs (2015) conducted a comparison of German and US educational study programs with a relation to media pedagogy beyond teacher education. Institutes of Higher Education in Germany and the USA were analyzed in a broad online research to identify respective study programs. Based on a first online inquiry about such programs, and with the intention of narrowing down the broad field of respective 
offerings, the following criteria were defined for including a study program: 1) Master's programs/graduate studies with a direct reference to media pedagogy (excluding initial teacher education), additional certificates and extended studies; 2 ) offered by institutions of higher education (i.e., universities and universities of applied sciences in Germany, excluding US colleges); 3) public institutions only.

The research was conducted independently for both countries by internet research, mainly based on several comprehensive listings of all universities within a country. This way, it was possible to identify $n_{G E R}=24$ study programs from $n_{\text {GER }}=17$ German institutions and $\mathrm{n}_{\text {USA }}=183$ study programs from $\mathrm{n}_{\text {USA }}=163$ US institutions. The relevant study programs identified were then listed, including information on (1) the institution, (2) the study program, (3) the degree, (4) the focus, (5) a program chair, coordinator or similar, and (6) an online link. To collect these data, online resources like webpages, study program descriptions and study handbooks were consulted. To draw comparative conclusions, the study programs identified were assigned one or several main foci which were defined in advance, deductively, based on the $\mathrm{M}^{3} \mathrm{~K}$ model of Medienpädagogische Kompetenz. These three main categories are media didactics/teaching with media, media education/teaching about media, and media-related school reform. Core outcomes of the study include the conclusion that there are peculiarities, but also shared characteristics of each system: e.g., media-related educational competencies can be acquired in both countries by (a) optional and elective courses during teacher education, (b) additional certificates and additional studies, or (c) graduate studies. Differences between the two systems relate, for example, to the role of school libraries and educational leadership graduates. With regards to the main foci of the study programs, there are comparable tendencies in Germany and the USA: media didactics is relevant in a majority of study programs of both countries, followed by school reform, while media education is subject to the study programs in the smallest number of the cases analyzed. Overall, both Germany and the USA are described to share comparable challenges, e.g., in terms of a comprehensive and nation-wide inclusion of media-related content into respective study programs.

Bearing in mind this overview on the status of integrating media-related content into initial teacher education in Germany and the USA, a number of consistencies and differences between the situations in both countries can be noted. A contextualization illustrates the overlaps between the media pedagogical discourses in both countries described, e.g., by Grafe (2011) and Blömeke and Paine (2008): both in Germany and the USA, the scientific communities (and further stakeholders, e.g., from a political context) emphasize the need for a systematic and obligatory inclusion of respective contents into initial teacher education and advance research to optimize processes in this regard. Yet the sources introduced above lead to the impression that there are slightly different viewpoints. German research, even from very recent 
sources, suggests a deficient and unsystematic inclusion of media-related contents and of media-related educational competencies into German initial teacher education, and a systematization of processes and further advancements to achieve a nation-wide obligatory inclusion appear as a dominant and reoccurring theme throughout sources from different backgrounds. In the US, it is necessary to differentiate between educational technology and media literacy, which are both included in the concept of media-related educational competencies but mostly treated separately in US research. Educational technology as a discipline was found to be integrated into virtually every teacher education program already in 2007, while the status of media literacy seems comparably uncertain but of increasing interest. Consequently, the interest of US research, particularly over the last few years, is less in improving the integration especially of educational technology on a structural level but rather in improving existing structures of integration and outcomes, which are described as equally deficient. Hence, the focus on infusing respective contents into methods classes and subject areas, as opposed to the stand-alone courses which were an efficient means of reliably ensuring a nationwide implementation in the first place but are now considered more critically as a second step.

Notably, such considerations are sometimes also suggested in German research, less in the sense of a replacement of respective focus courses but rather as an additional infusion (Sektion Medienpädagogik 2017; Spanhel 1997; 2017). In this context, Herzig et al. (2014) argue that, against the background of their capacities and content foci, chairs of subject didactics cannot be expected to systematically integrate media pedagogical contents into their curricula, which is why the task of a media pedagogical basic education for preservice teachers needs to be a task for educational science, even if an exploration and concretization within subject didactics is desirable. On the level of schools, such an integration into subject courses instead of distinct courses is claimed also from German political stakeholders (Bayerische Staatskanzlei 2017; Kultusministerkonferenz [KMK] 2012; 2016). This relates especially to the subject of computer science, which has an often discussed but overall close relationship to the field of Medienpädagogik. Based on a number of shared presumptions and objectives, computer science and Medienpädagogik approach the topics of media and IT from different angles. The establishment of a distinct subject "computer science" in schools is widely acknowledged, and a close cooperation between the occasionally competing research fields of computer science and Medienpädagogik is considered valuable in numerous sources to provide both students in school and preservice teachers in initial teacher education with competencies from both fields (Hauf-Tulodziecki 1999; Reiter 2010; Engbring 2018; Bayerische Staatskanzlei 2017; Herzig 2016; Tulodziecki 2016).

It was found already in the context of theoretical competency models from Germany and the USA that "content" as a distinct area has a different role in both 
countries. Also, the link between media pedagogy and media-related educational competencies, on the one hand, and subject or contents studies, on the other hand, was described to differ. Now, these differences are discernible also in practices of integrating media-related educational competencies into initial teacher education programs in Germany and the USA to a certain extent. In the USA, the established TPACK model emphasizes the importance of content as a core area of media-related knowledge. Consequently, practices of integrating respective models and competencies in the USA also focus on a content-integrated approach. In Germany, content is not integrated explicitly in central models of media-related educational competencies, and the special role of educational science within German teacher education comes into play and shapes the practices in advancing media-related educational competencies through a certain focus on distinct courses with media reference as, e.g., in the case of computer science.

The examples introduced in the overview on current practices in initial teacher education in Germany and the USA reveal different approaches to integrating media-related educational competencies on a university level, as there are obligatory and voluntary courses, profile-focused studies, certificates, extended or additional studies, or electives in content-matter courses. With regards to the German situation, it is noteworthy that there are many implementation modes that depend on preservice teachers' voluntary participation and elections. In combination with the obligatory study offerings in some places, these additional offers seem valuable in terms of the individualization of study paths and with regards to the chance for students to set their own foci and to specialize in their individual areas of interest. The non-binding nature of such offerings also gives considerable power to the universities as stakeholders because they are comparably flexible in the design of respective study offerings within their framework conditions given. However, from the voluntary approach a question arises about what this means for preservice teachers with less interest in media pedagogy, who are thus sometimes given the chance to avoid respective courses, although these students in particular can be expected to benefit from courses with a media pedagogical focus. Therefore, it becomes clear that the comparably large flexibility within the German system brings about certain challenges for the education of generic but non-obligatory study contents such as media pedagogy. A comparative view to the USA reveals that a system with fewer opportunities for electives and thus more fixed courses still leaves a certain freedom to the universities in their role as stakeholders: while the overall goal of the media-related education appears clear, there is still flexibility on the level of universities to set specific foci on the topics of educational technology and/or media literacy. To conclude, universities appear as a powerful stakeholder in the advancement of German and US preservice teachers' media-related educational competencies. However, there are also other stakeholders having an impact, central groups of which will be explored in the following. 
10. Stakeholders in the Advancement of Media-related Educational Competencies in Germany and the US

Analyzing the current German system of initial teacher education, Kotthoff and Terhart (2013) summarize pointedly:

"Teacher education in Germany is not only torn between the sometimes rather exaggerated and even contradictory demands of the different professional and non-professional actors involved (e.g. teachers, universities, ministries of education, teacher unions, parents, students etc.), but also between the various interests on local (e.g. institutional), regional (e.g. Länder), national (e.g. KMK) and European (e.g. 'EUROPEAN COMMISSION') levels.” (p. 86)

Indeed, the state of literature reviewed in the previous chapter regarding practices of advancing media-related educational competencies in Germany and the USA, as well as the previous considerations, suggest that a dense network of stakeholders and influences shapes practices in initial teacher education not only in Germany but also in the US. The interest groups mentioned by Kotthoff and Terhart (2013) can be restructured and amended by further stakeholders.

Generally, there is the societal context as a basic frame. Is has been argued above that research and practices in teacher education are always culturally shaped and influenced, which is why the society shapes expectations, experiences and the overall background of any practice in initial teacher education. Furthermore, related research and practices come into play as a background and reference for the decisions taken by actors in the advancement of the respective competencies. On the level of a more direct influence, Kotthoff and Terhart (2013) point out the role of institutions and political stakeholders. It has been mentioned above that there are binding regulations for the processes in question on the level of single states, and there are claims for regulations on a national level (cf. Chapter 9). Linked to this, organizations and societies have also been described above to have an impact on practices, e.g., by guidelines or standards, as in the case of ISTE and NAMLE (cf. Chapter 4). Finally, researchers and teacher educators play a central role as developers and users of concepts for the advancement of media-related educational competencies.

Considering these stakeholders on different levels, the roles of society and cultural background are quite general and inform decisions and practices indirectly. Hence, these influences are not of detailed interest for the following deeper analysis, even though the impact on a superordinate level is acknowledged. Likewise, the influences that local institutions of higher education and researchers and teacher educators can have on practices of advancement are comparably straightforward and were addressed in the previous chapter on current practices and the status quo. However, the level of policies and of professional organizations is not yet as clear. To systemize the ways in which influence is taken on political and institutional levels, 
the following chapter will summarize and analyze the respective facets in Germany and the USA. The examples selected for this purpose are not exhaustive and cannot illustrate their whole respective fields comprehensively. Their function is to highlight certain aspects and tendencies and to present national cases of practice with the overall aim of unraveling the network of influences and identifying key players.

The analysis is based on a broad database literature review on the related topics of policy regulations and institutional influences on initial teacher education and technology in teacher education. Additional internet sources, especially from governmental institutions and professional organizations, were added to the data to achieve a comprehensive picture of the practices in question.

\subsection{Educational Policy: Federal Level}

\subsubsection{Germany}

The German system of teacher education has a long history, which is characterized by long-lasting stability and hesitance towards reformation (Blömeke 2009; cf. ibid. for an overview of the historical, socio-economic and political characteristics of the system). It is also a vital element of this historical formation that the responsibility for education is largely with the 16 states. The influence of the federal government on education is rather low, because the long-established system of educational federalism, which dates back to the 19th Century, is fixed in the Basic Constitutional Law and grants the states cultural sovereignty (Hepp 2013). Remarkably, there are recurring and recently targeted attempts to adapt the respective law in order to loosen this strict division of power and to grant more influence to the federation by means of direct funding and cooperation with states in educational contexts (Deutscher Bundestag 2018).

An important stakeholder, which functions at the intersection of federal and state policies, is the Kultusministerkonferenz (KMK; Standing Conference of the Ministers of Education and Cultural Affairs of the Länder in the Federal Republic of Germany). Comprising the 16 ministers of education and cultural affairs, the KMK has the main task of self-coordination of the states, which is supposed to ensure unity, commonality, and comparability (Hepp 2013). An important outcome of the KMK are resolutions on a variety of topics, which have a high impact for all states. Against this background, the KMK has been repeatedly addressing the topic of media pedagogy, as several related resolutions prove. The overall message of these resolutions highlights the importance of media pedagogy in teacher education and schools and suggests an obligatory and extensive integration. For example, as early as 1983, the KMK declared media education a part of school lessons to enable students to use 
media responsibly and to develop and apply respective value-oriented attitudes (Kultusministerkonferenz [KMK] 1986; Tulodziecki 2016). In the 1990s, the concept of media education was increasingly linked to information technology approaches and included the idea of Medienkompetenz [media competence] (Kultusministerkonferenz [KMK] 1997; Tulodziecki 2016). This perspective was further developed in the 2000s by an additional focus on educational standards (Kultusministerkonferenz [KMK] 2005; Tulodziecki 2016). A resolution from 2012 was of particularly high impact, as it was agreed by all states that a sufficient and obligatory integration of media pedagogy into educational science and into subject-specific teacher education in the first and second phase of teacher education is necessary and needs to be included in examination regulations (Kultusministerkonferenz [KMK] 2012, 7; cf. also 1995; $1998 ; 2004 ; 2012 ; 2016$, for further related resolutions). However, the role of the KMK resolutions remains an advisory one, and it is within the responsibility of the states to put them into practice, as will be outlined in Chapter 10.2.

Despite the cultural sovereignty of the states, the federation does have a certain influence on higher education policy beyond the KMK, because the states depend on financial aid from the federation (Hepp 2013). The coordinating main stakeholder in this field is the Bundesministerium für Bildung und Forschung (BMBF; Federal Ministry for education and research), representing the federation in cooperation with the states and on a European and international level. The BMBF has taken various steps in researching and fostering media-related educational competencies in teacher education. Examples for this engagement include the report "Kompetenzen in einer digital geprägten Kultur" (competencies in a digitally influenced culture; Bundesministerium für Forschung und Bildung [BMBF] 2010), where the explicit and unaffiliated integration of media pedagogy into all fields of pedagogical education is considered obligatory; the research program "Kompetenzmodellierung und Kompetenzerfassung im Hochschulsektor" (Modeling and Measuring Competencies in Higher Education), which also funded the development of the afore-mentioned $\mathrm{M}^{3} \mathrm{~K}$ model of Medienpädagogische Kompetenz (Herzig et al. 2015; Zlatkin-Troitschanskaia et al. 2017); or the "Qualitätsoffensive Lehrerbildung" (quality initiative for teacher education), an initiative funded by the federation, as represented by the BMBF, which invests up to 500,000,000 Euros in institutions of teacher education for innovative projects and recently added a focus on digitalization in teacher education after an interim evaluation (Bundesministerium für Forschung und Bildung [BMBF] 2016; 2019; Brümmer et al. 2018; van Ackeren et al. 2019).

In the past, criticism has been expressed towards the focus of federal politics as represented by the BMBF. With regards to the coalition agreement between the leading parties of CDU/CSU and SPD from 2014, there was criticism that a statewide fostering of students' media competence was not included, and that politics put too much emphasis on the digital economy, informatics, temporary supportive 
measures, and digital infrastructure, at the expense of structural changes in media education practices or effects on teacher education (Gesellschaft für Medienpädagogik und Kommunikationskultur [GMK], \& Keine Bildung ohne Medien [KBoM] 2014). However, recent developments, like the emphasis of digitalization in teacher education in the funding line Qualitätsoffensive Lehrerbildung by the BMBF and the inclusion of opinions from experts in the field of related research (van Ackeren et al. 2019), illustrate an increasing awareness of the necessity of advancing preservice teachers' media-related educational competencies systematically.

\subsubsection{USA}

The influence of the US federal administration on education is generally subordinate, because the responsibility for schools and colleges, for the development of curricula, and for enrollment and graduation requirements is primarily with the states, local communities and with public and private organizations, according to the US Department of Education. As the Department describes, the federal role in education rather functions as a kind of "emergency response system" (U.S. Department of Education 2017b). Yet there are two core missions of this federal department. The first mission is leading on and facilitating a national dialogue about improvements in the educational system, and the second mission is financial support (ibid.). This financial support is primarily aimed at students, with the purpose of ensuring equal conditions (U.S. Department of Education 2017a).

However, the perception and appreciation of the role of federal influence on education and its actions and measures are dependent to a certain degree on the current administration. As US Secretary of Education Betsy DeVos recently declared, "President Trump is committed to ensuring the Department focuses on returning decision-making power back to the States, where it belongs" (U.S. Department of Education 2017b). In April 2017, President Trump initiated a review of federal education policies to identify and rescind regulations and guidelines that interfere with local or state authority in education matters (Green 2017). This Education Federalism Executive Order is targeted at former administrations' efforts to impact, improve and shape teacher education nation-wide, within the boundaries given.

Since the creation of the Department of Education in 1980 under president Jimmy Carter as a key representative and instrument of federal influence on educational state policies, there were repeated attempts, mostly from the Republican Party, to abolish it (Baumann and Read 2018). The latest of these attempts was represented by a bill in Congress which suggested terminating the whole Department of Education on December 31, 2018. President Trump approved of this step (GovTrack.us 2017). This bill was not enacted but has been updated to terminate the department on December 31, 2020 (GovTrack.us 2019). 
Within this restricted frame, valid means for taking governmental influence on education are declarations, acts, and national plans. Examples of significant impacts include the No Child Left Behind Act (NCLB) of 2001 or the Race to the Top (RTTT) grant program of 2009. In practice, NCLB led to colleges and schools of education rethinking their existing programs and giving a stronger emphasis to subject matter preparation in teacher education. RTTT had a strong impact in terms of accountability and achievement measurement (Wiseman 2012).

The Department of Education has also shown interest and engagement in media-related issues in the past. The Office of Educational Technology published several relevant documents, with visions and recommendations included in the 2017 National Education Technology Plan (U.S. Department of Education, Office of Educational Technology 2017). This plan includes a chapter on "rethinking teacher preparation" and highlights the importance of a comprehensive inclusion of technology into teacher education (p. 35). This topic is explored in greater detail in the "Advancing Educational Technology in Teacher Preparation: Policy Brief" (U.S. Department of Education, Office of Educational Technology 2016), which serves to

"identify key challenges and solutions to the effective integration of technology in teacher preparation, provide guiding principles on how to move the field toward effective integration of technology in teacher preparation programs, and identify areas of opportunity and collaboration for stakeholders across the field." (p. 6)

Hence, it can be summarized that the role of the US federal administration in teacher education is controversial and subject to change, depending on the respective administration and governmental stakeholders. The overall influence is rather low and limited to non-binding recommendations and plans, and to financing.

The comparison between the German and the US system reveals wide overlaps. In both cases, the influence of the federal government on educational practices, and for that matter on the advancement of media-related educational competencies, is existent but limited to financing and recommendations, plans, etc. A difference can be noted with regards to the public perception of this role of the federal government, which is established in Germany but of less certain status in the USA. 


\subsection{Educational Policy: State Level}

\subsubsection{Germany}

Within the 16 states, the Kultusministerien (ministries of education) are the authorities responsible for education. Thus, the state governments have a say in the curricula of teacher education, which includes some general regulations for every study program and final exams to ensure comparability (Blömeke 2009). In accordance with the scope and intention of this work, this chapter will focus on state regulations for the first phase of German teacher education, which is the university-based scientific and academic education. Yet it should be noted that the influence of the Länder is not limited to this dimension: in the second phase (Referendariat), where teachers start teaching while being mentored, the training institutions are organized by the state governments. Representatives of the government also enact regulations and monitor exams (ibid.).

The principle of cultural sovereignty grants autonomy to the states in educational matters, as outlined in Chapter 10.1. All in all, a system characterized by heterogeneity of educational state policies developed out of educational federalism (Brautmeier 2013). Consequently, there are also individual regulations in the 16 German states with regards to the role of media pedagogy and media-related educational competencies in initial teacher education programs. To achieve an overview of these regulations within the 16 states, the Monitor Lehrerbildung offers a comprehensive source. In the context of this nation-wide project, Bertelsmann Stiftung et al. (2018) introduce relevant data from a survey concerning the preparation of future teachers for working and teaching with digital media. 63 institutions of higher education and all of the 16 German states participated in this survey (ibid.).

According to Bertelsmann Stiftung et al. (2018) and KMK (2016), there are basically two major measures German states can implement to force the inclusion of media-related educational competencies into initial teacher education programs, even though the actual implementation is in the responsibility of institutions of teacher education. These measures include respective aims in objective agreements or contracts between state and institutions of higher education, on the one hand, and establishing the respective competencies as a precondition for entering the practical phase of German teacher education, or including them into state regulations for final exams, on the other. Out of 10 states that answered this part of the survey, two states discussed including the topic in objective agreements or contracts between state and institutions of higher education, and two other states confirmed planning this measure. Five states indicated acknowledging the topic in state regulations for final exams, and three states announced planning respective measures. One state also 
stated applying other measures, and two states indicated planning other measures (Bertelsmann Stiftung et al. 2018).

Table 14 lists selected results from the survey to contribute to a comprehensive picture of respective curricular regulations. The data illustrate the shares of states with state-wide obligations regarding media-related educational competencies, structured according to school forms, and thus indicate how much the influence of state governments has led to an obligatory advancement of these competencies in current practices.

\begin{tabular}{|c|c|c|c|c|c|c|}
\hline \multirow[t]{2}{*}{$\begin{array}{l}\text { State-wide obliga- } \\
\text { tion to offer courses } \\
\text { for the acquisition of } \\
\text { professional compe- } \\
\text { tencies for ... }\end{array}$} & School form & $\stackrel{\Perp}{\check{\nu}}$ & 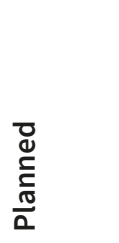 & 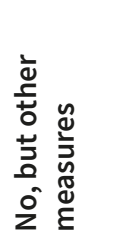 & 운 & 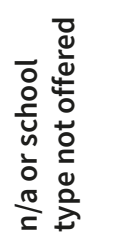 \\
\hline & & n states & n states & n states & n states & n states \\
\hline \multirow[t]{3}{*}{$\begin{array}{l}\text {... handling digital } \\
\text { media }\end{array}$} & $\begin{array}{l}\text { ITE for Elementary } \\
\text { school }\end{array}$ & 5 & 4 & 3 & 1 & 3 \\
\hline & $\begin{array}{l}\text { ITE for Secondary } \\
\text { school, level I }\end{array}$ & 5 & 3 & 3 & 1 & 4 \\
\hline & $\begin{array}{l}\text { ITE for Secondary } \\
\text { school, level II (gen- } \\
\text { eral education) }\end{array}$ & 4 & 4 & 3 & 3 & 2 \\
\hline \multirow{3}{*}{$\begin{array}{l}\text {... the methodolog- } \\
\text { ical-didactic imple- } \\
\text { mentation of digital } \\
\text { media in school }\end{array}$} & $\begin{array}{l}\text { ITE for Elementary } \\
\text { school }\end{array}$ & 4 & 5 & 1 & 2 & 4 \\
\hline & $\begin{array}{l}\text { ITE for Secondary } \\
\text { school, level I }\end{array}$ & 4 & 4 & 1 & 3 & 4 \\
\hline & $\begin{array}{l}\text { ITE for Secondary } \\
\text { school, level II (gen- } \\
\text { eral education) }\end{array}$ & 4 & 5 & 1 & 4 & 2 \\
\hline
\end{tabular}

Tab. 14.: State-wide regulations for the acquisition of media-related educational competencies (data retrieved from Bertelsmann Stiftung et al., 2018).

As Table 14 indicates, state-wide regulations on media-related educational competencies are indeed implemented heterogeneously. With regards to the implementation of digital media into initial teacher education and the advancement of competencies in handling media, some states, such as Saxony, do without respective regulations for all school forms, while others have or plan obligatory regulations for some or all school forms, or describe "other measures" (ibid.).

Also, in the case of the obligatory advancement of professional competencies for the methodological-didactic implementation of digital media in school, there are states without regulations for all school forms, states with respective regulations for some school forms enacted or planned, and states applying "other measures." It 
is important to note that an assignment to the category "no regulations" does not automatically mean that there are no respective activities. The state of Hesse, for example, did not indicate having obligatory courses. Yet there are efforts there to advance media-related educational competencies with preservice teachers. As early as 2003, a working group named "Neue Medien in der universitären Lehrerbildung" (new media in teacher education at universities) was established, led by the ministry of education in Hesse (HKM) and the ministry of research and arts (HMWK), to develop a concept for media competence in the first phase of teacher education (Bremer 2011a), including the definition of competency standards (cf. Chapter 4.3). A recent development in Hesse based on these efforts is a portfolio for media education competence, an instrument for state-wide application which allows preservice and inservice teachers to voluntarily track and visualize their competency development in five competency areas: media theory and society, didactics and methodology of implementing media, media use, media and school reform, and the role of teachers and personal development (Hessisches Kultusministerium 2017; Pleimfeldner 2017). Hence, it can be summarized that, though there may not be obligatory regulations, there are still supportive measures, even though Hesse did not indicate "other measures" in the Monitor Lehrerbildung (Bertelsmann Stiftung et al. 2018).

This finding leads to the conclusion that it is challenging to summarize and abstract the unique approaches every state has to the advancement of media-related educational competencies by fixed categories. However, there is value in a comparative and necessarily abstractive approach like Monitor Lehrerbildung due to its comprehensive perspective on practices in Germany, and due to the challenges and recommendations derived by the approach. There are five core challenges identified from the data introduced above and further survey results:

1. The strategic steering by the states is insufficient so far;

2. Digital media are mostly just optional study contents;

3. A practical testing of digital media is scarcely provided obligatorily;

4. Institutions of higher education act too isolated and network too little;

5. The use of digital media in ITE courses is not facilitated consequently enough by strategic design processes (Bertelsmann Stiftung et al. 2018, 15-18).

To meet these challenges, recommendations are formulated in the Monitor Lehrerbildung on different levels. With regards to the structural level, the recommendations include establishing digital media as an obligatory topic, anchoring it on an institutional level, and creating appropriate supportive structures. In terms of networking practices, better connections of theory and practice in ITE are suggested and the support of networks of institutions of higher education and networks with external actors. Considering the increase of motivation, effective incentives should be installed for respective developments (Bertelsmann Stiftung et al. 2018, 19-23). 
These recommendations comply with respective claims from the literature mentioned above, e.g., by Blömeke (2003), Kammerl and Mayrberger (2011), or Imort and Niesyto (2014).

It will be analyzed below how far these practices identified in Germany relate to US practices.

\subsubsection{USA}

As pointed out above, the departments of education in individual US states are responsible for the education of future teachers, and every state has unique state-level requirements and tests for graduates of teacher education programs seeking licensure. The political engagement at the state level is coordinated by state departments and commissions (e.g., Connecticut State Department of Administrative Services 2019). Beyond obligatory or elective study offerings, as in the examples mentioned, the efforts of state-level political stakeholders include recommendations and general directive advice, which often refer to schools and media literacy education and educational technology instruction at schools. This can be seen in several bills, such as Bill No. 2128 in Massachusetts acknowledging the need for media literacy education in the context of sexual health education (General Court of the Commonwealth of Massachusetts 2017), or Bill No. 194 in New Mexico suggesting appropriating a media literacy program for school teachers (Cisneros 2019).

In contrast to Germany, where there are formal frame conditions for teachers to work in any state once they have been certified, US teacher certification is usually tied to the states to such an extent that teachers who want to work in another state have to apply for certification there (Watson, Murin, and Pape 2014). This structure brings about a high autonomy in the states, creating a direct impact on the contents and outline of teacher education programs. Universities have to make sure that their teacher candidates comply with state requirements and are well-prepared for exams. The requirements for initial teaching licensures are usually regulated by state standards to fulfill the requirements imposed by the Council for the Accreditation of Educator Preparation (CAEP).

No comprehensive studies could be found comparing the status of educational technology and media literacy education in teacher preparation curricula or respective state standards in a way comparable to the systematic German Monitor Lehrerbildung. Yet there are a number of related publications and findings that highlight the implementation of respective competencies and contents, either with regards to educational technology or to media literacy in related contexts, and thus emphasize the importance of advancing these competencies in initial teacher education. Such findings will be presented in the following section. It focuses on educational technology in state policies, educational technology and media literacy in K-12 education, 
and on further state-wide approaches to advancing competencies in relation to educational technology and media literacy at the level of teachers.

With regards to educational technology, the map "Digital Instructional Materials Acquisition Policies for States" provides "state and territory policies and practices related to the acquisition and implementation of digital instructional materials in K12 education" (State Educational Technology Directors Association [SETDA] 2019). It reveals an overview of policies about digital instructional materials as one specific aspect from the field of competencies in educational technology, and it gives a first impression about the ways in which these aspects are relevant across US states in relation to inservice teachers and practices in $\mathrm{K}-12$ education. Table 15 lists selected aspects with a reference to educational technology in an overview.

\begin{tabular}{|c|c|c|}
\hline Topic & Aspect & $\begin{array}{l}\text { No. of states } \\
\text { where the as- } \\
\text { pect applies }\end{array}$ \\
\hline \multirow{8}{*}{$\begin{array}{l}\text { Guidance and } \\
\text { Policies }\end{array}$} & Guidance Accessible Digital Instructional Materials & 30 \\
\hline & Guidance Accessible Technologies & 28 \\
\hline & $\begin{array}{l}\text { State Statute - Allows Implementation of Digital Instructional } \\
\text { Materials }\end{array}$ & 32 \\
\hline & $\begin{array}{l}\text { State Statute - Instructional Materials Adoption - Digital Mate- } \\
\text { rials Included }\end{array}$ & 18 \\
\hline & $\begin{array}{l}\text { State Statute - Instructional Materials Adoption - Online Con- } \\
\text { tent Included }\end{array}$ & 17 \\
\hline & $\begin{array}{l}\text { State Statute - Instructional Materials Adoption - Software } \\
\text { Included }\end{array}$ & 15 \\
\hline & State Statute - Online Course Requirement & 8 \\
\hline & $\begin{array}{l}\text { State Statute - Requires Implementation of Digital Instructional } \\
\text { Materials }\end{array}$ & 3 \\
\hline \multirow{5}{*}{$\begin{array}{l}\text { Professional } \\
\text { Learning }\end{array}$} & Development of OER & 16 \\
\hline & Implementation of Digital Instructional Materials for Learning & 20 \\
\hline & Selection of Digital Instructional Materials for Learning & 22 \\
\hline & $\begin{array}{l}\text { Technical Assistance - Accessible Instructional/Educational } \\
\text { Materials }\end{array}$ & 25 \\
\hline & Technical Assistance - Accessible Technologies & 20 \\
\hline \multirow{3}{*}{$\begin{array}{l}\text { Digital Learn- } \\
\text { ing }\end{array}$} & Digital Learning Plan & 32 \\
\hline & Digital Learning Standards for Students & 29 \\
\hline & State Requirements for District Digital Learning Planning & 19 \\
\hline
\end{tabular}

Tab. 15.: Selected aspects from the Digital Instructional Materials Acquisition Policies for States (data retrieved from SETDA, 2019).

The table reveals that certain aspects from the context of educational technology are important in several US states and have state-wide importance for K-12 
educational contexts. The aspects concerning state statutes in particular are revealing, as they show, e.g., that there is a requirement to implement digital instructional materials in three states, or a requirement for online courses in eight states. This is tangential to the dimension of media-related educational competencies in educational technology because teachers need specific competencies to cope with these tasks successfully. Likewise, the other aspects mentioned in Table 15 either require or support the acquisition or advancement of media-related educational competencies, as in the case of "Selection of Digital Instructional Materials for Learning" (ibid.) which clearly relates, for example, to DigCompEdu competency "Selecting digital resources" (Redecker 2017, 16). However, the numbers of states where aspects identified by this map apply show, again, large heterogeneity and limited consent across the 50 states.

Focusing on the K-12 student perspective, the Common Core Standards are another relevant source, as they outline the knowledge and skills in mathematics and English language that arts/literacy students should have acquired at the end of each grade. These standards have been adopted in 41 states (Common Core State Standards Initiative 2019) and are an important reference for K-12 teachers, as they have to make sure their students comply with the requirements. The Common Core State Standards show multiple references both to the fields of educational technology and media literacy. For example, students who are college and career ready are expected to "use technology and digital media strategically and capably" (Common Core State Standards Initiative n.d., 7), and grade 5 students have to be able to "analyze how visual and multimedia elements contribute to the meaning, tone, or beauty of a text (e.g., graphic novel, multimedia presentation of fiction, folktale, myth, poem)" (ibid., p. 12). These references, too, highlight the importance of teachers integrating educational technology and media literacy systematically on a state level and thus claim respective competencies on the side of teachers. However, with regards to media literacy, related literature has been critical of the focus of the Common Core State Standards as too limited. This is because it does not specifically refer to critical analysis or the production of different media offers, nor does it foster critical analysis of media messages and representations (Beach and Baker 2011). Based on a 1999 study, the authors conclude that elements of media literacy were already found in almost every state's teaching standards - but their focus may be narrow because they widely rely on the Common Core State Standards (ibid.; cf. also Cooper Moore and Bonilla 2014, for an extended analysis of the relationship between media literacy education and the Common Core State Standards). Consequently, the NAMLE Core Principles of Media Literacy Education amend and redefine desirable learning outcomes in the field of media literacy (cf. Chapter 4.2), but they are not implemented as a state-wide standard by state regulations or governments. However, it has been pointed out recently that "a growing number of states [...] have introduced or passed 
bills and amendments to address media literacy education and digital citizenship in school based curricula" (Culver and Redmond 2019, 1).

Beyond these $\mathrm{K}-12$ requirements, there are also single state-wide approaches and concepts in relation to educational technology and media literacy that extend the focus to preservice and beginning teachers in single cases. Findings from these approaches are summarized in Table 16.

\begin{tabular}{|l|l|l|}
\hline Target group & Approach & Source/example \\
\hline $\begin{array}{l}\text { Preservice } \\
\text { teachers }\end{array}$ & $\begin{array}{l}\text { State-wide educational technology endorsement program } \\
\text { as an elective study offer }\end{array}$ & $\begin{array}{l}\text { Utah Education } \\
\text { Network (uen; } \\
\text { n.d.) }\end{array}$ \\
\hline $\begin{array}{l}\text { Beginning } \\
\text { teachers }\end{array}$ & $\begin{array}{l}\text { Inclusion of standards with reference to educational tech- } \\
\text { nology and media literacy within state-wide examinations } \\
\text { of beginning teachers }\end{array}$ & $\begin{array}{l}\text { Texas Education } \\
\text { Agency (2019) }\end{array}$ \\
\hline $\begin{array}{l}\text { Inservice } \\
\text { teachers }\end{array}$ & $\begin{array}{l}\text { Alignment of state standards for teachers with ISTE stand- } \\
\text { ards }\end{array}$ & $\begin{array}{l}\text { MissouriState } \\
\text { (n.d.); Post (2004) }\end{array}$ \\
\hline
\end{tabular}

Tab. 16.: Selected state-wide approaches in relation to media-related educational competencies.

In terms of obligatory state-wide regulations, the example of Texas is particularly interesting because of the proximity to the regulations described in Germany. In the state of Texas, there are seven standards within the Technology Applications EC-12 Standards with requirements expected of all beginning teachers and included in the obligatory Texas Examination of Educator Standards (TExES) Pedagogy and Professional Responsibilities (PPR) test (Texas Education Agency [TEA] 2019). These standards include the following: standard II: "All teachers collaborate and communicate both locally and globally using digital tools and resources to reinforce and promote learning" (Texas State Board for Educator Certification 2016, 2); standard III: "All teachers acquire, analyze, and manage content from digital resources" (ibid.); and standard V: "All teachers practice and promote safe, responsible, legal, and ethical behavior while using technology tools and resources" (ibid.). To this degree, these standards are closely related to competencies described by DigCompEdu or $\mathrm{M}^{3} \mathrm{~K}$.

In conclusion, it can be summarized that state policies in Germany and the USA share characteristics, especially from a systemic viewpoint, with regards to legislative autonomy and responsibility, but they differ in aspects of realization. With regards to legislative systems, both countries have a system of cultural sovereignty within a certain framework that allows states to shape and impact practices in initial teacher education with regards to the advancement of media-related educational competencies. The impact state legislatures can take in this context is comparable in certain regards. As described above, there are state-wide graduation exams in both countries where the responsible state authorities can - and sometimes do - prescribe 
an obligatory examination of graduates for aspects related to Medienpädagogische Kompetenz, educational technology, or media literacy.

The status of the advancement of media-related educational competencies in initial teacher education in German states, as proposed by state policies, is well-documented, especially by the Monitor Lehrerbildung, and it is clearly regulated in several cases. In the US, the situation appears less consistent. There are multiple references to state regulations at the $\mathrm{K}-12$ level and some with regards to inservice teachers. Both indirectly influence initial teacher education in terms of the expectations for graduates. However, direct regulations concerning the advancement of media-related educational competencies in initial teacher education are scarce and less well-documented.

In the light of these conclusions, it can be noted that both Germany and the USA yet face comparable challenges. There is an increasing awareness of the necessity to advance media-related educational competencies with preservice teachers in both countries, but the autonomy of states in educational issues results in heterogeneous realizations of state-wide regulations. Hence, the impression is substantiated that there are stakeholders working on levels other than states and policy, which will be explored in the following.

\subsection{Institutions and Initiatives}

Beside political stakeholders, there are established non-governmental institutions and initiatives which aim to impact the advancement of media-related competencies in initial teacher education in a number of ways. These stakeholders can be grouped roughly into professional societies and associations, on the one hand, and industry-based or commercial stakeholders on the other. There are of course cross-references between the two groups.

\subsubsection{Germany}

\section{Professional societies and associations}

A key player in this context is the Division 12, Media Education, of the Deutsche Gesellschaft für Erziehungswissenschaft (DGfE) or German Educational Research Association (GERA). The GERA is an association of German educational researchers that generally aims to promote study, research and education in the area of educational theory and science (Deutsche Gesellschaft für Erziehungswissenschaft [DGfE] n.d.). It is structured by 14 divisions, each focusing on a specific topic within the field of interest. Activities of division 12, Media Education, include conferences, support for 
young academics, annual books, and the facilitation of discussion and information amongst members. Among other achievements of this division, there are two particularly relevant outcomes in the context of media-related educational competencies. They are the "Orientierungsrahmen für die Entwicklung von Curricula für medienpädagogische Studiengänge und Studienanteile" (Framework for the development of curricula for media pedagogical study programs and study contents; Sektion Medienpädagogik 2017) and the initiative "Keine Bildung ohne Medien!" (No education without media!).

The framework "Orientierungsrahmen für die Entwicklung von Curricula für medienpädagogische Studiengänge und Studienanteile," published in 2017 by Sektion Medienpädagogik, is highly relevant in the context of media pedagogy in educational study programs. In response to current discourses in educational policy, it offers comprehensive guidelines for the design of (new) media pedagogical study programs. It builds on and continues the national discourse about an obligatory basic education in media pedagogy, which was initiated and advanced by a number of national stakeholders (Sektion Medienpädagogik 2017).

The "Keine Bildung ohne Medien!" initiative is a joint initiative of several organizations and persons from the field of media pedagogy. Its main goal is the largescale, systematic and sustainable inclusion of media pedagogy into all educational fields in society, which also comprises a claim for an obligatory basic education in media pedagogy for all pedagogical study programs. Activities of this initiative include various publications, e.g., recommendations and commentaries on current topics, conferences, and political engagement (Kommer 2019).

A selection of further important stakeholders in the field of media pedagogy includes the JFF (Institute for media pedagogy in research and practice), the GMK (Professional Association for Media Education, and Media Literacy and Communication Culture), the GFD (Association for Fachdidaktik), and the GMW (Society for Media in Science). The JFF highlights a connection of research and practice for the purpose of fostering media competencies and media literacy, and it conducts and offers various activities like evaluation studies and projects - but also pedagogical practical offerings for recipients of all kinds (JFF - Institut für Medienpädagogik 2018). The GMK describes itself as both the largest professional umbrella association for institutions and individuals and a platform for discussion, cooperation and new initiatives. Like the JFF, the GMK also fosters media pedagogy and media literacy and highlights an interplay of research and practice. It also plays an active role in the consultation of educational policy (Gesellschaft für Medienpädagogik und Kommunikationskultur [GMK] n.d.). The GFD has a slightly different focus, as this association is concerned with Fachdidaktiken, i.e., subject didactics. From this perspective, the GFD highlights the role of media pedagogy in relation to subject didactics and postulates a close collaboration and merging of the two disciplines (Gesellschaft für Fachdidaktik e.V. 
[GFD] 2018). Finally, the GMW is a professional association for the implementation of media in higher education. It assumes a media didactical viewpoint by researching and supporting the application and use of media in research, teaching at university and further university-related fields (Gesellschaft für Medien in der Wissenschaft e.V. [GMW] 2019).

Industry-based and commercial stakeholders

Relevant stakeholders with a relation to industry and commercial backgrounds in Germany include the Netzwerk Digitale Bildung [Network for Digital Education], the Initiative D21, and the Deutsche Telekom Stiftung. The Network for Digital Education explicitly aims to transfer the dialogue about the digitalization of the educational system from restricted professional associations to a broader audience. It fosters debates about digital education and the innovative design of future-ready learning scenarios and links funding parties from industry with non-commercial cooperation partners, pedagogues and experts from research (Netzwerk Digitale Bildung n.d.). As a nonprofit network, the initiative D21 even extends the range of partners to include policies, industry, research and civil society. It addresses all sorts of societal challenges related to the digital evolution by fostering debates and supporting and publishing research and solutions - this includes questions of initial teacher education (Initiative D21 e.V. 2019). Finally, the Deutsche Telekom Stiftung is one of the larger German company-related foundations supporting projects and research around the field of digitalization and education, such as the Forum Bildung Digitalisierung or the Monitor Lehrerbildung (Deutsche Telekom Stiftung 2019). These examples can be amended by a range of further foundations and initiatives active in this field with differing foci. A list of the largest German foundations is provided by Bundesverband Deutscher Stiftungen (n.d.). It includes the Bertelsmann Stiftung, which is another impactful stakeholder in the context of media-related educational competencies. It funded a project which then led to the development of a model of Medienpädagogische Kompetenz (Tulodziecki 2012), and it is also involved in the systematic evaluation of practices in advancing media-related educational competencies in German initial teacher education (cf. Chapter 9). This example illustrates the importance foundations can have for the context of modeling and advancing media-related educational competencies. 
Professional societies and associations

There are a number of institutions and initiatives in the US which impact the facilitation of media-related competencies in teacher education in several ways. The International Society for Technology in Education [ISTE] is of central relevance in the context of educational technology. ISTE is a nonprofit organization of educators that aims to foster the integration of technology in schools. As the core objective is summarized on their homepage, the "ISTE inspires educators worldwide to use technology to innovate teaching and learning, accelerate good practice and solve tough problems in education by providing community, knowledge and the ISTE Standards, a framework for rethinking education and empowering learners" (International Society for Technology in Education [ISTE] n.d.). On a national level, ISTE has become widely acknowledged and well-established (Siller 2007, 95). They offer practical guidance, opportunities for professional learning, virtual networks, events, and the ISTE standards (International Society for Technology in Education [ISTE] n.d.). These standards address and provide a framework for all levels of the educational system and for all stakeholders: currently, there are ISTE standards for students, educators, administrators, coaches, and computer science educators (ibid.). They define what the respective target group should know and be able to do in the context of handling and using information technology (cf. Chapter 4.2). Through the ISTE standards, ISTE has a high impact on technology in teacher education; they are widely recognized and used in multiple ways across the US, affecting all other levels of stakeholders. The US Department of Education encourages using the ISTE standards (U.S. Department of Education, Office of Educational Technology 2016; 2017). Some states, such as Ohio, align their curricula and standards with the ISTE standards (Post 2004) or even prescribe state-wide inclusion into teacher education, as in Texas (Randles 2017). Several universities (as well as a range of educational resources) have been granted the ISTE seal of alignment to confirm that they correspond to the principles of the ISTE standards. For example, some institutions installed ISTE.T certification programs, offering a certificate for students who fulfill the requirements as proposed by the ISTE.T standards (e.g., the James Madison University) or have accordingly designed study programs (e.g., the online Master's program in Educational Technology at California State University Fullerton; International Society for Technology in Education [ISTE] n.d.).

A second influential society is the Society for Information Technology and Teacher Education [SITE]. Describing itself as "the only organization solely focused on integrating technology into teacher education" (Society for Information Technology and Teacher Education [SITE] and Association for the Advancement of Computing in 
Education [AACE] 2019) and thus oriented towards a narrower focus than ISTE, the SITE contributes to the discourse on educational technology in teacher education primarily by developing and disseminating knowledge and research through conferences, books, projects, and a related journal (ibid.).

Davis (2003) adds the following organizations to this category: the Association of Teacher Education (ATE), and the American Association of Colleges of Teacher Education (AACTE), both of which form networks in their fields related to teacher education.

In accordance with the twofold focus in the US on educational technology and media literacy, multifold activities in the field of media literacy are organized by a distinct association, the National Association of Media Literacy Education [NAMLE]. While there are further interest groups playing a role in media literacy education in the US (e.g., https://medialiteracynow.org; https://www.medialit.org), NAMLE is particularly relevant for the advancement of media literacy competencies in initial teacher education by means of their publication of the NAMLE Core Principles of Media Literacy Education (cf. Chapter 4.2). NAMLE is a nonprofit organization with the mission "to be the leading voice, convener and resource to foster critical thinking and effective communication for empowered media participation" (National Association for Media Literacy Education [NAMLE] n.d.). Respective activities include conferences, leadership councils, publications, summer institutes and research to live up to the aspired objectives and lead on the evolution and spread of media literacy across the US.

Furthermore, teacher accreditation agencies, which are non-profit organizations, are influential institutions in this context; through their accreditation of teacher education programs and providers, they directly impact the competencies future teachers will acquire. Two core institutions were the National Council for Accreditation of Teacher Education [NCATE] and the Teacher Education Accreditation Council [TEAC] who merged to create the Council for the Accreditation of Educator Preparation [CAEP] in 2013. There are CAEP standards for the accreditation of educator preparation providers; they are partly based on the ISTE standards and hence include references to fostering preservice teachers' media-related educational competencies, such as in standard 3.4: "Providers present multiple forms of evidence to indicate candidates' developing content knowledge, pedagogical content knowledge, pedagogical skills, and the integration of technology in all of these domains" (Council for the Accreditation of Educator Preparation [CAEP] 2019, 2). 
Industry-based and commercial stakeholders

According to Bakir (2016), further interest groups with an industry background and business collaborations come into play as influential stakeholders with initiatives in the US context of advancing media-related educational competencies. Among them are the CEO Forum on Education and Technology, the Milken Exchange on Educational Technology Group, who partnered with ISTE (Milken Exchange on Education Technology 1999), and the Partnership for 21st Century Skills, all of which contribute to the current practices in teacher education by research, recommendations, core principles, etc.

The overview of key institutions having an impact on practices of advancing media-related educational competencies in initial teacher education in Germany and the USA is necessarily selective. It can only give a first impression into the complex network of institutional stakeholders. However, it serves to illustrate two main points. First, groups of institutional stakeholders share certain characteristics in Germany and the USA: both comprise nonprofit associations and initiatives contributing to competency advancement, as they foster dialogue through conferences, publications, etc. They influence practices in teacher education through guidelines or standards of different kinds. Industry-based stakeholders come together and work with politicians, researchers and civil society in networks and initiatives. Remarkably, these industry-based stakeholders and initiatives often follow a nonprofit-approach, which does not, however, exclude marketing purposes, political objectives and an overall dense network of interests inherent in the multifold activities. A difference between German and US stakeholder groups can be noted with regards to the accreditation of study programs. In the US, CAEP was mentioned as a stakeholder because of its direct effect on the contents of initial teacher education, which is put into practice also through respective standards. In Germany however, there is less influence of accreditation institutions on curricular contents. Here, the Stiftung Akkreditierungsrat (foundation accreditation board) functions as a central decisive committee and has been responsible for accepting or declining the accreditation of study programs for all 16 states, including initial teacher education programs, since 2018. The full members currently comprise representatives from institutions of higher education, political representatives of federal states, industry representatives, students, and representatives of international universities and thus form a consortium of stakeholders from different contexts (Stiftung Akkreditierungsrat n.d.). However, their impact primarily refers to the quality and feasibility of study programs and less to a content level, which is why the German Stiftung Akkreditierungsrat has not been included in the previous list of stakeholders. Yet it remains a shared characteristic of German and US academic systems that teacher education programs have to meet formal requirements and complete an accreditation process, which is, therefore, an important condition for the implementation. 
The overview presented further provides a background to the respective sources introduced in Chapter 4 and contextualizes the results. This outcome is linked to the second conclusion from the overview, referring to the separation of educational technology and media literacy research in the USA. The systematic differentiation in US concepts is mirrored in the relevant organizations that have an impact on advancing respective competencies in initial teacher education. It is noteworthy that this concentration is to a certain degree also observable with German associations and societies. Despite the comprehensive German concept of Medienpädagogik comprising both facets of Mediendidaktik (teaching with media) and Medienerziehung (teaching about media), some of the societies mentioned focus on only one of these dimensions. Examples are the GMK, with its orientation towards Medienerziehung, and the GMW and industry-based initiatives, with their emphasis on Mediendidaktik.

This summary of selected practices of advancing media-related educational competencies in German and US teacher education shows that both countries share many comparable preconditions, for example in the context of political influence on federal and state levels. Yet there are also differences, as in the case of the federal institutions of education policy, which have limited influence in both countries mainly due to funding; in terms of reputation and perceived usefulness, federal governmental institutions are stable and well-established in Germany but of less secure status in the US. Discourses about ways of integrating the respective competencies into initial teacher education also differ in some cases: in the US, the current focus is on infusing educational technology into curricula and on rendering educational technology courses unnecessary, while the German research discourse often suggests combining both formats, even though opinions vary across stakeholders, interest groups and research foci. All in all, the special role that educational science plays in German teacher education offers a frame for the integration of respective educational technology courses. This is unique to the German system of teacher education.

This chapter on the status quo in German and US teacher education has reached its conclusions based on related literature and research of publicly available resources. However, the juxtaposition of conditions also implies certain blank fields, as in the case of empirical comparative evidence. To substantiate and amend these findings it is necessary to achieve comprehensive and subject-specific conclusions by utilizing measures of empirical research, especially against the background of missing empirical evidence on German and US practices of advancing media-related educational competencies in initial teacher education. To fill this gap, a respective study will be introduced in the following. 


\section{Comparing Practices in German and US Teacher Education}

To explore and confirm the theory-based findings from Chapters 9 and 10 in greater depth, and to add a substantial comparative perspective, a study based on expert interviews was selected. This approach is supported by Schiefner-Rohs (2012), who suggests researching practices of advancing media-related educational competencies in initial teacher education by methods such as interviews.

\subsection{Expert Interview Methodology}

Expert interviews, a special type of guided interview, are a common category of research tools in qualitative social research. They can be defined as a systematic and theory-based approach for data collection, put in practice as interviews with persons who have exclusive and specialized knowledge in a specific field of interest (definition translated and adapted from Kaiser 2014, 6; cf. also Collins and Evans 2007). According to Kaiser (2014; cf. also Bogner, Littig, and Menz 2009; Brenner 2006; Flick, Kardoff, and Steinke 2004), this definition implies three central concepts, which relate to the criteria of good quality established in social sciences, i.e., objectivity, validity, and reliability. First, the requirement of a systematic procedure seeks to ensure intersubjective traceability of the methods of data collection and data analysis as far as possible. Such intersubjective traceability cannot fully be achieved in the context of qualitative expert interviews because the measurement tool does not offer a sufficient degree of standardization; yet the processes of data collection, analysis and interpretation should be explicated in order to allow for an external review. To do justice to this claim, the following chapter on methodology will explain in detail how the expert interviews were prepared, conducted, and analyzed.

A second implication of the definition is that the research approach needs to be theory-based, meaning that preparation and analysis of the interview materials should refer to existing related research sources (Kaiser 2014). In the case of the study described, this claim is met by a broad integration of related literature in two ways: on the one hand, the contents of the interview were selected on the basis of, and grounded by, respective research, as for example with regards to relevant models or stakeholders in the context of initial teacher education. On the other hand, the research methodology was designed in accordance with related methodological literature to ensure a sound and valid research approach.

The third implication relates to the kind of knowledge or expertise that is to be evoked by the interview. This expertise requires neutrality and open-mindedness in the face of new aspects, differing relevance attributions and interpretive patterns on the side of the researcher. This requirement is necessarily restricted by the respective research process, which demands decisions and selections in favor of certain aspects and interpretive preferences (ibid.). Yet, in the present study, neutrality is 
aimed at by means of a carefully prepared interview guideline which leaves room for open and unbiased contributions and excludes suggestive or loaded questions.

Against this background of genuine research preconditions, expert interviews have a number of more specific and practical characteristics. As guided interviews, they are usually semi-structured (Bogner, Littig, and Menz 2014), which means that there is a set canon of interview questions requiring open answers. Hence, the interview is pre-structured but also demands flexibility because the expert's contributions are to be included and reacted to, for example by changing the order of questions according to the direction the interview takes.

It is the role of the expert that determines the unique characteristics of expert interviews. According to Przyborski and Wohlrab-Sahr (2014), experts can either have expertise in institutional contexts, i.e., they are representatives of an institution and knowledgeable about procedures, rules and mechanisms in these contexts; or they can have interpretive expertise, i.e., they are able to analyze and interpret things in a predefined context; or they have a special context knowledge about areas which are of interest for the study (Kaiser 2014). For the following study, the experts selected were required to have all three kinds of expertise. In detail, the criteria for the selection of experts in the study were: 1 ) an affiliation with a German or US institution of initial teacher education and experience in teacher education, and 2) scientific work and relevant publications in the fields of technology or media pedagogy in teacher education, educational technology, media literacy, media-related competencies or related fields. The first of these two requirements was defined to ensure an adequate background and working experience, and thus a suitable reference frame for the interview, while the second requirement served to make sure that the participants had adequate expertise and scientific reliability and were established researchers in the field of interest. This field was defined broadly to account for varying concepts and foci within the area of media-related educational competencies.

The interviews in this study were developed, conducted and analyzed according to the first seven steps of Kaiser's (2014) methodology. In detail, this includes the following stages:

1. Developing an interview guideline: based on the preceding literature review, central steps for the development included brainstorming, structuring of contents, sequencing and phrasing questions and estimating timing (Krueger and Casey 2015).

2. Pre-testing the interview guideline: both the German and the English version were pre-tested with persons who met the criteria for the expert selection. The German pre-testing did not yield any potential for improvement of the guideline. The results were considered meaningful and relevant in the aftermath, so it was decided to include the pre-testing into the study as regular data. This decision was made based on the high quality of the experts' information, which were assumed 
to enrich the overall data, and it is consistent with the methodology suggested by Kaiser (2014). The English pre-testing revealed several starting points for improvement to enhance clarity and quality of language, which were then realized to inform the final guideline.

3. Selecting and getting into contact with interview partners: the experts were identified according to the criteria mentioned above, based on a combination of established contacts, internet research, and snowball sampling. Contact was established via emails, and interviews were planned for $n=10$ experts, i.e., $n=6$ from the USA and $n=4$ from Germany. The slightly uneven numbers account for the heterogeneous size of both research communities and limited availability and accessibility of German experts.

4. Conducting the expert interviews: the interviews were realized by online videoconferences from June to August 2018.

5. Recording the interview situation: the interviews were video recorded by a screen capture software.

6. Saving the results (record or transcription): the recordings were transcribed by student assistants (German) and professional transcriptionists (English) and double-checked at random. Both versions were peer-reviewed.

7. Coding the material: the transcribed material was coded using the coding software MAXQDA (Mayring 2015). The category system applied was prepared deductively and in advance based on the literature and related sources, which were also used for the design of the expert interviews and amended iteratively by inductively derived additions in the process.

For data analysis and further steps, Kaiser (2014) suggests identifying central statements, extending the data basis, and creating theory-based generalizations and interpretations. Instead of following this procedure, the data analysis was performed by a deductive qualitative content analysis, following Mayring (2015). This combination of approaches was chosen because Mayring's (2015) approach to qualitative content analysis is established in social sciences research and has been acknowledged as a standard for respective studies (Kohlbacher 2006), while Kaiser (2014) refers to the context of political research. The step of extending the data basis, in particular, is less common in social sciences. Mayring's (2015) methodology offers a more suitable approach. Hence, the following steps, 8 and 9 , were added instead:

8. Content analysis: the coded material was analyzed qualitatively following Mayring (2015). The structure predefined by the codings facilitated a meaningful and systematic analysis, which led to a number of insights and conclusions.

9. Presentation of results: the results were then summarized, presented in Paper 2 (cf. Chapter 11.2) and at SITE conference 2019 in Las Vegas, USA, and amended by further considerations in Chapter 11.3 of this dissertation. 


\subsection{Paper 2: The Integration of Media-Related Studies and Competencies into US and German Initial Teacher Education. A Cross-National Analysis of Contemporary Practices and Trends ${ }^{2}$}

\subsubsection{Introduction}

It is an important and valuable observation that for some years now, considerable efforts have been made to include media-related studies into initial teacher education - a process which has been recognized as highly desirable and necessary (Redmond 2016; Gronseth et al. 2010). There are a number of stakeholders taking influence on these developments: for example, there are national plans and lines of funding published by federal governments (in Germany: BMBF 2016; in the US: U.S. Department of Education, Office of Educational Technology 2017). Also, several associations and initiatives publish guidelines and standards intended to shape the contents of teacher education curricula (Sektion Medienpädagogik 2017; ISTE 2017).

Against the background of these efforts, there is a large variety between the ways in which institutions, states and countries take influence. So far, there is no clarity about these processes in research, although the value of respective considerations e.g. for schools and policy makers has been acknowledged (Redmond 2016). To achieve a comprehensive exploration of media-related preservice teacher education and to understand the ways in which this important task is realized, the study introduced in the following considers factors that impact the field of interest in different ways. There are four main perspectives which contribute to the overall picture: (1) theoretical foundations, (2) external influence and conditions, (3) practices of implementation, and (4) outcomes. From the theoretical perspective, models of media-related educational competencies from both countries will be included to illustrate the foundations and basic assumptions about competencies that preservice teachers should achieve. External influence and conditions will be addressed by considerations about stakeholders who actually impact and shape media-related teacher education. With regards to current practices, the ways in which respective study offerings are integrated into teacher education, e.g. by voluntary or obligatory courses, will be considered, and finally, the outcomes of these processes will be discussed. Since neither Germany nor the US have binding regulations for the integration of media-related educational competencies into teacher education, the overall status appears heterogeneous and inconsistent, and this paper has the purpose of

2 Originally published as:

Tiede, Jennifer, and Silke Grafe. 2019. "The Integration of Media-Related Studies and Competencies into US and German Initial Teacher Education. A Cross-National Analysis of Contemporary Practices and Trends". In Proceedings of Society for Information Technology \& Teacher Education International Conference, edited by K. Graziano, pp. 1709-1717. Las Vegas, NV: Association for the Advancement of Computing in Education (AACE). ISBN 978-1-939797-37-7. https://www.learntechlib.org/primary/p/207873/. Copyright by AACE. Reprinted with permission of AACE (http://www.aace.org). 
clarifying respective processes to provide a sound basis for further research and developments in this important area.

\subsubsection{Approaching Media-Related Studies from a Cross-National Comparative Per- spective}

For the following study, it is beneficial to take on a cross-national comparative perspective and to include more than one country to avoid cultural and national bias and a narrowed perspective. As Blömeke and Paine (2008) point out, cross-national research helps take advantage of the experiences and perspectives of different countries, and it facilitates researchers to overcome the constraints of their own cultural background and to include various points of view. This is particularly appropriate for a topic with such a strong cultural commitment as education, because respective processes in teacher education are dependent on a network of factors such as cultural identity and history, the demands and influence of society, or the respective pedagogical research discourse and tradition. The cross-national comparative research aims to take advantage of such individual contexts and to overcome their constraints by contextualization. Taking into account new perspectives will be beneficial for a realistic and possibly new perception of one's own background, and it is valuable for efforts of reform and improvement.

Against this background, Germany and the USA have been selected because they offer a valid background for respective comparative considerations. Their systems of teacher education, which is central for the topic, shows structural similarities: both countries are federal systems with a relatively high autonomy of the states in educational matters, and both the USA and Germany have a rich tradition of pedagogical discourse and critical debates about the system of teacher education. They also share basic Western values of democracy and the role of education (Tiede and Grafe 2016).

\subsubsection{Media in US and German Teacher Education: State of the Art}

In the US, media-related studies are integrated into the fields of educational technology and media literacy education. The concept of educational technology shows references to the German understanding of 'teaching and learning with media' or Mediendidaktik. As Mayrberger and Kumar (2014) point out, the study fields of educational technology and Mediendidaktik are clearly related but cannot be used as synonyms or translated due to differences in their conceptualization, background, institutionalization etc. (cf. also Grafe 2011). Likewise, the field of media literacy education is related to the German concept of 'teaching and learning about media' or Medienerziehung. 
In the German educational research discourse, Mediendidaktik and Medienerziehung are understood as two central aspects of the construct of Medienpädagogik, defined as "the entity of all pedagogically relevant, action-guiding considerations in relation to media, including their media technological and media theoretical or empirical and normative foundations" (Tulodziecki, Herzig, and Grafe 2010, 41; own translation). There is no equivalent term in English, since the concepts of educational technology and media literacy education tend to be understood as distinct fields of study rather than as two aspects of a superordinate concept (Grafe 2011). According to Bereday (1964), finding a neutral superordinate category or term instead of applying terminology or concepts from one of the objects that are to be compared is essential for a neutral and unbiased perspective in international comparative research. Hence, in the following the fields of educational technology, media literacy education and Medienpädagogik will be referred to as media-related studies in teacher education in the sense of a tertium comparationis (Bereday 1964).

German education has a robust tradition of competency orientation, which has led to numerous research works that consider, define and measure competencies and competency models in higher education (Zlatkin-Troitschanskaia, Pant, Toepper, Lautenbach, and Molerov 2017). Within this tradition, various approaches to modeling and measuring Medienpädagogische Kompetenz have been developed. Medienpädagogische Kompetenz literally translates as 'media-pedagogical competence' and describes the competencies which teachers should have in the outlined field of Medienpädagogik. Beside competencies in Mediendidaktik and Medienerziehung, the construct also includes further aspects depending on the source, such as media-related school reform competency (Herzig, Martin, Schaper, and Ossenschmidt 2015; Blömeke 2000), socialization-related competency (Blömeke 2000) or own media competency (Blömeke 2000). In the following, the term media-related educational competencies will be used as a tertium comparationis for the competencies that teachers should have in the context of media-related teaching and learning.

Models of media-related educational competencies from the German national context are e.g. the approaches by Tulodziecki (2012) and Blömeke (2000), and the $\mathrm{M}^{3} \mathrm{~K}$ model (Herzig, Martin, Schaper, and Ossenschmidt 2015; Tiede and Grafe 2016). In the USA, a well-established model in the field is the TPACK model (Mishra \& Koehler, 2006). Apart from TPACK, there are numerous US guidelines and standards which serve to define competencies or skills for teachers in relation to media and assume functions comparable to German competency models. Two popular examples from this field are the ISTE standards (ISTE 2017) and the NAMLE Core Principles of Media Literacy Education (NAMLE 2007).

It has been described a central condition for optimizing educational processes and for ensuring and developing quality in the educational sector to model and measure competencies (Fleischer, Koeppen, Kenk, Klieme, and Leutner 2013), but 
there is a gap between claims of research and actual practices in teacher education. Several research works have pointed out a deficient and unsystematic integration of Medienpädagogik or medienpädagogische Kompetenzen into German initial teacher education, e.g. by Schiefner-Rohs (2012) and Kammerl and Mayrberger (2014). Respective findings for the US situation in relation to media literacy education have been formulated e.g. by Redmond (2016) and Flores-Koulish (2006). Educational technology has been described as better integrated: as early as 2007, Kleiner, Thomas, Lewis, and Greene summarized that $100 \%$ of all US teacher education programs provide instruction on technology integration. The contents, foci and outcomes of these instructions however are heterogeneous (Gronseth et al. 2010).

With regards to comparative studies, Tiede, Grafe and Hobbs (2015) comparatively analyzed educational study programs with a distinct media-related focus in Germany and the USA and summarized that the study programs are quite heterogeneous and do not represent the aspects of medienpädagogische Kompetenz equally. In an international survey on curricula of media literacy education completed by $n=65$ experts from 20 countries, Fedorov, Levitskaya and Camarero (2016) researched productive sources of media literacy education curriculum, content and learning outcomes of media literacy education curriculum, assessment strategies of students' media literacy competence, and main challenges for media literacy curriculum design and implementation. A qualitative consideration of curricula and practices in media-related studies from an internationally comparative perspective has not been published so far.

\subsubsection{Research Methodology}

It is the aim of the study presented in the following to explore current practices and trends in German and US media-related initial teacher education by gathering and analyzing experts' opinions qualitatively. Hence, the data were collected by expert interviews. Criteria for the selection of experts in the study were: 1) an affiliation with a German or US institution of initial teacher education and rich experience in teacher education, and 2) scientific work and relevant publications in the fields of educational technology and/or media literacy education or Medienpädagogik in teacher education, media-related educational competencies or related fields, and 3) agreement to participate in the study. The number of potential experts in this field was found to be limited especially in Germany, and the number of US experts was adjusted to approximately match the German equivalent. Hence, in accordance with these criteria a sample of $n=11$ experts, i.e. 5 experts from Germany and 6 experts from the USA, was included into the study. These two groups are understood to give an appropriate insight into the situation of their respective country due to the width of their expertise and research foci: the sample includes experts from the fields of 
educational technology, media literacy and Medienpädagogik. Also, the experts come from different states and thus account for the educational federalism within their respective country. As the design of this study follows a deductive approach, the sample was determined in preparation of the study, based on a literature review, grounded theoretical considerations and in consideration of the total population of appropriate experts and of the breadth and scope of research questions (Bryman 2012). The fact that a certain theoretical saturation was achieved after the interviews (Fusch and Ness 2015) supports the assumed appropriateness of the final sample for this research.

The deductive approach of the study included an initial literature review and theoretical groundwork as a basis for the interview guideline. This guideline was then pre-tested and, in case of the English version, improved with regards to terminology to enhance precision and clarity. Then, appropriate interview partners were identified by a combination of literature review, internet research and snowball sampling, and contacted. The interviews took place via video conferencing tools (i.e., Skype and Zoom) and were recorded and then transcribed (Kaiser 2014). For the content analysis as suggested by Mayring (2015), the transcribed material was coded using the coding software MAXQDA, following a deductive category system which was prepared in advance based on theory. In accordance with the research interest, the main categories were "Relevant models, guidelines, standards etc.", "Aspects of media-related educational competencies / outcomes", "Integration into ITE", "Stakeholders", and "Subjective assessment". This way, the experts' statements were analyzed and then summarized and described, which will be subject to the following chapter.

\subsubsection{Findings from the Expert Interviews}

\section{Theoretical Foundations}

One essential part of the interview served to identify central models, guidelines, standards and other sources which are the foundation for integrating media-related studies into initial teacher education.

With regards to models and guidelines, the source which was described most often within the sample of US experts to have an impact on practices in teacher education were the ISTE standards, which seem to be relevant for a significant number of teacher education programs across the United States (ISTE 2017). Some experts with a focus on media literacy mentioned the NAMLE Core Principles of Media Education as a reference for their work in teacher education (NAMLE 2007). Also, TPACK (Mishra and Koehler 2006) was perceived as important and widely established, although there were also critical voices calling this model too "abstract" or "problematic" and 
"a deficient model" due to the separation of knowledge domains which the expert prefers to understand as one interconnected domain. Such criticism is in accordance with concerns also raised in related literature, e.g. by Graham (2011).

Asking the US experts about models and competencies also brought about insights into the general attitudes about this field. As the literature review revealed, modeling media-related educational competencies is not as an established practice in the USA as it is in Germany. Some experts supported this conclusion by stating that they do not work with the term competencies at all, and that they do not necessarily favor using scientific models or standards as a background for teacher education.

The German experts mentioned several models and sources which they considered a foundation for fostering media-related educational competencies of German preservice teachers, repeatedly pointing out that there is no consensus or standard in this regard. However, they frequently referred to the works of Blömeke (e.g. 2000) and Tulodziecki (e.g. 2012), and several experts also mentioned the $\mathrm{M}^{3} \mathrm{~K}$ model (Herzig, Martin, Schaper, and Ossenschmidt 2015). Furthermore, in terms of international references the TPACK model (Mishra and Koehler 2006) and DigCompEdu (Redecker 2017) were mentioned as relevant. Also in the sample of German experts, some opinions revealed a critical reflection of the suggested usage of models as a foundation of teacher education. They consented that teacher education study programs are mostly not tied to a model or designed with a theoretical model as a reference explicitly, but rather geared to the implications and requirements of current practices in schools.

\section{External Influence and Conditions}

Teacher education is a practice which is dependent on numerous stakeholders and influences, including policy, culture, history, society, economy, schools, and many others (Blömeke 2009). The following section highlights actors which are of particular importance for the experts interviewed.

Policy: While the US experts disagreed on the importance of federal policy - some rejected any federal influence on their work, while others pointed out the impact especially of federal funding, initiatives and the Common Core Standards -, there was agreement that the states significantly impact the practices in teacher education by standards, regulations, accreditation and certification, to a varying extent and depending on the state. The German experts agreed consistently that one of the most important political stakeholders in the German context is the Kultusministerkonferenz [KMK; Standing Conference of the Ministers of Education and Cultural Affairs of the Länder]. As further political stakeholders, the German experts identified the Bundesministerium für Bildung und Forschung [BMBF; Federal Ministry of Education and Research], primarily taking influence by funding, and the 16 German Länder, 
which specify and implement the KMK resolutions and are autonomous enough to uniquely shape the media-related teacher education in their sector.

Associations and initiatives: US experts agreed that institutions, associations, initiatives and similar are also significantly impacting practices in teacher education. As pointed out before, ISTE and NAMLE play a predominant role in this context mainly through their standards or core principles, but also through building communities and promoting knowledge, research and communication. Further stakeholders mentioned are Common Sense Media, the National Council of Teachers of English (NCTE) Media Literacy Now, and the Association of College and Research Libraries (ACRL). Likewise, the German experts assigned some importance to societies and associations, even though they tended to be more critical and questioned their role. Central players mentioned were e.g., the Deutsche Gesellschaft für Erziehungswissenschaft (DGfE; German Educational Research Association), teachers' associations or the initiative Keine Bildung ohne Medien! (KBoM!; No education without media).

Companies: The US experts acknowledged the fact that companies and the technology industry, e.g. Google, Apple, Intercall, and Pearson, also have an interest in impacting teacher education practices and offer according resources and solutions. The engagement of such companies was perceived as problematic due to their focus on selling products, but some experts also mentioned good examples such as the New York Times learning network and appreciated funding and initiatives, e.g. by Google. Even beyond their products, companies and the industry are described as important stakeholders because they have requirements for future technically savvy employees who have to be educated in schools, which claims appropriately educated teachers. The German experts described the impact of companies as focusing on expectations and interests in future employees with high digital skills, which requires an according education and thus also claims appropriately educated teachers.

Schools: Schools and their students were mentioned in the context of stakeholders because they have requirements and expectations for future teachers, which teacher education has to satisfy. The same can be said about the wider society, which similarly has expectations and requires teacher education to deliver certain results in terms of media literate and technology-savvy teachers. Digitalization has become a society-wide catchphrase and infuses all areas of education. These observations were shared by experts both from the USA and Germany.

Beyond external influences, there are four dimensions of stakeholders at the university, according to US experts. The first dimension is the university administration, which is described to have only a subordinate influence. It is rather at the second level, which is boards, committees etc., where trend-setting decisions with regards to curricula are made. However, the US experts agreed that there is a significant and large autonomy of teacher educators, who are among the most important stakeholders and form the third dimension. In many cases, teacher educators 
have a considerable amount of flexibility in terms of the contents they teach and in their teaching methods and focus. Finally, the forth group of stakeholders at the university is the group of preservice teachers themselves. In a way, they impact their own media-related education by feedback and by the choices they make in terms of courses and course projects, if they are given a choice, which is rarely the case in US undergraduate teacher education. They also shape their teacher education programs by the experiences and attitudes they bring along. Beyond the proceedings at single universities, US experts described that the universities also influence each other, which is due to the strongly hierarchical structure of US universities: what happens at the universities with the highest reputation "will be kind of aspirational for the other, smaller teacher education programs around the country".

Also in Germany, the role of the universities is central. The universities' administrative bodies may shape a general orientation towards media, but it is at the level of chairs and most significantly of the teacher educators where important choices are made and where the integration or fostering of Medienpädagogik happens. This impact was perceived as even more important than regulations and obligations, because the teacher educators decide about the ways in which they implement such elements, and about the competencies they want to foster and the ways in which they assess the outcomes. This autonomy is beneficial in a way, because it allows teacher educators to follow their convictions and to set foci as preferred. At the same time, it is risky because teacher educators also have the power to decide against the inclusion of Medienpädagogik, and because an engaged inclusion of respective contents depends on single persons with according interests. According to the German experts, the role that German preservice teachers play is also vital. Due to the unique characteristics of the system of German teacher education (cf. Blömeke 2009, for an overview), which allows for great flexibility and autonomy in selecting courses as compared to the US, the preservice teachers in many cases have a say in the courses they take and therefore in the Medienpädagogik they encounter. Again, this is beneficial for preservice teachers who have respective interests and are media savvy, but it is problematic for those that are negligent of or critical towards media, which seems to be the case with peculiarly many German preservice teachers according to the experts.

\section{Practices of Implementation}

Based on former research, it was assumed that the respective study contents can either be integrated as obligatory courses, as electives, or as parts of other courses and content areas. While in the US study sample obligatory educational technology courses were described to be widely established, media literacy courses seem to be rare. However, the experts' opinions revealed that distinct and obligatory educational 
technology or media literacy classes may not be the best way to integrate according knowledge at all: "In a perfect world, there would be no need for an education technology course on the pre-service level. We would see instructors integrating digital technologies quite naturally with their own instruction". In accordance with this, several experts described that these fields are integrated rather often into other courses such as methods classes or subject-specific or discipline classes. However, this apparent heterogeneity within the system also led to the conclusion that students could at some places complete their teacher education without ever learning about media literacy or, in fewer cases, about educational technology. Voluntary offers or electives for media-related studies were described to be very rare at the level of preservice teacher education due to fixed curricula without electives and also due to a heavy workload preservice teachers face.

The German experts also pointed out that the ways in which Medienpädagogik is integrated into German teacher education are not standardized and thus highly heterogeneous. There are university-wide or even Länder-wide obligatory courses, which are required for all preservice teachers at some places and range from single courses to more comprehensive modules. Against the background of the flexible German preservice teacher education system which allows for a number of individual choices, it is a common procedure also to offer voluntary courses which preservice teachers can opt to take. This heterogeneity again leads to a situation in which preservice teachers at some places can graduate without ever learning about Medienpädagogik. The German experts repeatedly mentioned a significant third practice for conveying respective contents, which is the integration into subject-specific courses. There is a growing number of teacher educators in subject-specific courses employing contents and methods from the field of Medienpädagogik - a practice which the experts generally approved of, even if they pointed out a bias due to the unsystematic approach. This is in accordance with some US experts' claim for a natural integration of media-related studies into other courses instead of specific educational technology or media literacy courses.

\section{Learning Outcomes and Competencies Acquired}

The experts were asked for the outcomes of media-related teacher education in their country, i.e. the aspects of media-related educational competencies preservice teachers acquire, and the things they learn from the domains of educational technology and media literacy education, or Medienpädagogik. In this context, in the US interviews it became obvious that the distinction between educational technology and media literacy education is disputable. While it was confirmed that the two are understood as two separate domains, which are interrelated and overlap at some point, some experts approved of this separation and others criticized it. Also, the US 
experts avoided the term competencies, sometimes explicitly explaining that it is not common and in other cases describing skills, knowledge or outcomes rather than competencies.

The preservice teachers' learning outcomes described by US experts are shaped again by heterogeneity and depend on the focus of the experts. Competencies in "teaching and learning with media" or educational technology mentioned included for example strategies for using videos in class, digital pedagogy, how and which media to use in class, and reflective practices. Outcomes in "teaching and learning about media" or media literacy education included e.g. student empowerment, teaching for social justice, teaching about social media and fake news, critical evaluation, and responsible behavior online. It was also described that students acquired practical and technological competencies, such as operating and applying specific tools, websites, blogs etc., or recording videos. The degree to which these different aspects of competencies are achieved differ. The experts were confident that a majority of preservice teachers are provided with basic technological skills, but the acquisition of deep knowledge with regards to educational technology and even more with regards to media literacy education seems to be unsystematic and dependent on numerous factors, including the conditions and stakeholders as described above.

Some German experts also put into question the acquisition of proper competencies in initial teacher education. Instead, they repeatedly highlighted the importance of conveying attitudes, beliefs and an increased awareness of the field of Medienpädagogik and of its implications and importance for school. Against this background, the main outcome described in the field of "teaching and learning with media" or Mediendidaktik was reflecting on the reasonable inclusion of media into teaching and learning processes, with some experts confirming this outcome and others challenging it. Outcomes in the field of "teaching and learning about media" or Medienerziehung included e.g., a reflection on different perceptions of Medienerziehung, the relation of media and identity, or cyberbullying. Further comments referred to the field of media-related school reform or organizational aspects, which was described to be of subordinate importance but sometimes addressed. German preservice teachers were also described to acquire practical skills such as using apps or devices.

\subsubsection{Discussion and Implications}

The results described above offer relevant insights into practices of teacher education in Germany and the USA. There are several differences between both systems which became obvious in the interviews and deserve further research. A first observation in this context is that media-related teacher education in Germany and the USA is based on different assumptions about competency modeling. In Germany, modeling and measuring competencies is well-established and considered important for a 
systematic inclusion of central facets (Fleischer, Koeppen, Kenk, Klieme, and Leutner 2013; Blömeke, Zlatkin-Troitschanskaia, Kuhn, and Fege 2013). However, the German experts' experiences show that such a systematic approach is not a common standard, and that current practices of media-related teacher education employ heterogeneous ways of fostering respective competencies. Yet, the German experts pointed out references of the practices they described to models and theoretical approaches, most centrally from Germany, but also with regards to international approaches. The US experts in the study on the other hand explicitly or implicitly rejected the term competencies. This finding questions the appropriateness of the tertium comparationis of media-related educational competencies, which was thereby discovered to carry a predominantly German tendency and will thus need rethinking for further related studies.

The US experts also challenged the role of theoretical models, preferring practical guidelines like the ISTE standards or the NAMLE core principles and referring to the US background only. The rather subordinate role that scientifically sound and well-researched models of media-related competencies play for actual practices, certainly in the USA and in many cases also in Germany, leads to questions of the genuine role that such competency models can and should play in teacher education. It has been pointed out in related German literature that competency modeling and measuring can be a vital contribution to establishing, maintaining and improving quality in higher education systematically, but the expert interviews from Germany and even more so from the USA convey the impression that there are other factors more powerfully guiding actual practices. Given the value that research-based competency models can have for practice, further research in this field will have to intensify efforts not only in investigating and developing respective models but also in considering their potential for and actual implementation into practices in teacher education to ensure a closer connection of research and practice.

A second implication to be learned from the expert interviews is connected to the role of teacher educators. Both in Germany and the USA, teacher educators turned out to be a key stakeholder for the facilitation of media-related educational competencies. This is true for teacher educators in educational courses, but also for teacher educators from all other fields including content-specific courses in particular. The experts in the study described that media-related studies are not tied or limited to educational classes, and this leads to two conclusions. First of all, it is desirable to strengthen the collaboration between educational experts in media-related fields and teacher educators from other fields, and to develop approaches which allow for a more systematic and grounded inclusion of media-related studies into content-specific courses. As the experts pointed out, this connection is already established to a certain point because also teacher educators from other fields use media in their classes, but it needs support, research and innovative approaches to support 
the comprehensive and genuine integration of respective contents into teacher education and to resolve the limitation to distinct educational courses. The second conclusion is that teacher educators are an important, but sometimes neglected target group for media-related competency research. The interviews revealed that teacher educators play a central role, and that the decisions teacher educators take with regards to e.g. contents and methods are amongst the most decisive factors in the network of facets determining the media-related education that preservice teachers receive. Research has only begun to consider what this means for the teacher educators' attitudes and competencies (Krumsvik 2012; Foulger, Graziano, Schmidt-Crawford, and Slykhuis 2017), and further research will be beneficial for supporting and enhancing all teacher educators" willingness for and skills and competencies in integrating media into their classes.

It is an important observation that these conclusions are true both for the German and the US context, and this supports the initial assumption that the cross-national comparative perspective can be beneficial and point out global and superordinate tendencies. For future considerations, it will be helpful to build on the strength of a cross-national perspective and to include more countries and backgrounds to enhance understanding about global requirements and overall tendencies. Researchers and practitioners alike should encourage collaboration and combine efforts for fostering and improving the systematic integration of media-related studies into teacher education, which has turned out to be a process only at its beginning and characterized by heterogeneous conditions and requirements, but also full of potential and supported by qualified researchers and teacher educators who are working on improving the current practices with great engagement.

\subsection{Main Conclusions from and Further Perspectives on Paper 2}

Paper 2, "The Integration of Media-Related Studies and Competencies into US and German Initial Teacher Education. A Cross-National Analysis of Contemporary Practices and Trends", amends the perspectives offered so far by including perspectives on current practices in initial teacher education in both countries investigated. These perspectives include the fields of 1 ) theoretical foundations, 2) external influence and conditions, 3) practices of implementation, and 4) learning outcomes and competencies acquired. In terms of the theoretical foundations at the basis of media-related efforts in teacher education in Germany and the USA, the expert interviews revealed that in the USA the ISTE standards are widely established as a theoretical background for orientation, with the NAMLE Core Principles of Media Education and TPACK as more controversial sources. The German experts referred to a number of research-based models of Medienpädagogische Kompetenz, including the works of Blömeke, Tulodziecki and $\mathrm{M}^{3} \mathrm{~K}$, and to international approaches like TPACK and 
DigCompEdu. The identified external influences and outer conditions which determine processes and contents in teacher education could be classified into policy, associations and initiatives, companies, schools, and different levels of stakeholders at universities. With regards to practices of implementation, media-related contents were found to be integrated either as obligatory courses, as electives, or as parts of other courses and content areas to differing degrees: e.g., electives were found to be a comparably rare phenomenon in US teacher education, at least at undergraduate level. Finally, media-related learning outcomes and competencies that students acquire in the course of their teacher education were described as quite heterogenous, including technical skills or knowledge in the pedagogical implementation of digital media into lessons.

Key conclusions of the paper refer to a different notion and treatment of the term competencies and of the role of theoretical models, to the important stakeholder position of teacher educators, and to the applicability and advantages of cross-national comparative research in general.

With regards to the different notion of competencies, it has been mentioned in the conclusion of Paper 2 that a certain terminological variety concerning this term, and sometimes even its rejection, could be observed. Considering competing terms, in some statements, competencies was circumscribed or interfused with skills, understanding and comparable terms, as in the following:

"In my role facilitating what I would call media education or media literacy with preservice teachers, I would describe these skills I'm trying to build as more thinking skills, critical thinking skills, ways of understanding media technology that position them beyond just a value-neutral device [...]." (expert US6)

"Students are coming out of Ed schools without a good understanding of how to use technology and media and that they bring their media skills that they've learned as growing up as young people." (expert US1)

From a terminological point of view, these statements substantiate the claim that skills are sometimes used as synonyms for competencies (Sampson and Fytros 2008), and they show that the experts sometimes focused on skills as one component of the wider concept of competence (Tulodziecki and Grafe 2019; Weinert 1999; Blömeke, Gustafsson, and Shavelson 2015; From 2017; cf. Chapter 2). Hence, such a focus on distinct elements from the wider concept of competence can be read to substantiate the impression of diverging conceptions and foci within one extensive field.

Furthermore, the interpretation of an "explicit rejection" of the term competence is based on statements like the following: 
"When you were asking about competencies, I've been thinking a lot about this because it's a term that I don't use in my work. I think one of the things that we see happening, there's so much influence in the US of neoliberal policies that are trying to quantify everything and only valuing something that you can put a number [on] and quantify." (expert US2)

Overall, this explicitly dismissive statement reveals a narrow understanding of competencies as a means of quantification, testing and standardization and implies a negative connotation. From an international comparative viewpoint, it is remarkable that this point made by a US expert shows references to the debate around the questionable quantification and measurability of competencies which is a reoccurring theme in the German research debate (cf. Chapter 6), even though the expert expressing this criticism does not question the theoretical construct of competence and its quantifying dimension, but only practices of quantification. This relates to an aspect from the interviews which had to be neglected in the paper for reasons of length but is of high relevance for the context of this dissertation, namely the issue of measurement. Part II was concerned with different aspects of measurement and pointed out difficulties of measuring competencies, particularly with regards to the $\mathrm{M}^{3} \mathrm{~K}$ measurement instrument, model fit, and the international perspective and underlying cultural backgrounds. The expert interviews, however, brought forward a new dimension through criticism targeted at the measurement of competencies in general. Notably, this criticism was shared by voices from the USA and Germany alike:

"Testing and scripted standardized curriculum for teachers is becoming very, very popular and is one of the things that we're trying to push back on." (expert US2)

"I think what is relevant [...] is the question of what we can actually measure. I feel that most people think a model is a good model if I can operationalize and measure it. [...] This is less specific about media, but related to our standardized and measurement society in which we are from my point of view: everything needs to be evaluated, everything needs to be measured, everything needs to be quantified and I consider this a hazard especially for medienpädagogische Kompetenz, that we measure in schools only what is assessed in some way in PISA or in ICT competence. Everything else falls by the wayside." (expert D2, own translation)

Hence, according to some experts consulted, the measurement of media-related educational competencies does not only have to be considered from a methodological and content perspective but also with regards to its implications for students 
and society. There are repeated comments about both German and US societies, which increasingly tend to measure, quantify and standardize competencies. It will be a challenge for the future of the measurement of media-related educational competencies to define a position within this network of factors and to address the gap between what is demanded by, and helpful for, outer circumstances, such as society, and what is useful from a research and educational perspective. The study presented and the experts' comments quoted point to standardized and quantitative measurement instruments, but it is important to note that competency measurements can also have other purposes, such as individual feedback and subjective assessment of achievements, or supportive information for the orientation and improvement of processes and study programs. In accordance with that, the measurement of competencies is not limited to standardized quantitative instruments, as criticized above, but can also take on the shape of, for example, video-based observations and reflective evaluations to facilitate individual feedback. Naturally, such qualitative measures still imply a quantification of competencies; but the suggested negative sides of competency measurements will need a careful juxtaposition with benefits like those outlined above to come to a comprehensive judgment of the value of competency measurement beyond the implications of a "measurement society."

From a methodological perspective, the method of expert interviewing applied here does not allow for conclusions on the entity of the target group, i.e., US experts in the relevant field, because all statements represent single persons' subjective opinions and are therefore not representative of a specific group. Yet the examples of using other terms and presumed synonyms and of explicit rejection of the term competence hint at the conceptual vagueness which surrounds the field of media-related educational competencies, at least from a US viewpoint, and add to the impression of differing perceptions and concepts connected to competencies. In this context, it is worth considering that other US experts did, in fact, use the term confidently:

"I liked ISTE for the fact that it was focused on particular competencies and wasn't prescriptive about particular brands of tools or machines and devices, but rather competency-oriented, which I thought was appealing." (expert US5)

"I also think there needs to be a greater focus on particular competencies by educators and by schools to ensure that there are certain wider skill sets that are being learned and then like problem-solving and collaboration, as opposed to just ensuring that you've checked the box and students know how to use PowerPoint." (expert US5)

To conclude, the varying confidence in using the term competencies adds to the conceptual heterogeneity which characterizes the field of media-related educational competencies. This ties in with the initial observation that the term literacy is 
preferred within US research and that there is an established research tradition in the USA focusing on media literacy (cf. Chapter 2; see also Grafe 2011). Only recently, a shift towards an increasing US coverage of competencies can be observed as well, stimulated by the efforts and dissemination linked to the TETCs competency model of teacher educators' technology competencies (Foulger et al. 2017). It will be a promising objective for future comparative research to follow this development and to analyze what this will mean for the systematic distinction of educational technology and media literacy, which are now increasingly separated also by the differing concepts of technology competencies and media literacy. It is conceivable that these two will consequently contribute to an enhanced divisiveness. At the same time, the European research context shows how to integrate and synergize the concepts, thus offering innovative approaches for the US research context.

Another aspect which was discussed in the expert interviews but not included in Paper 2 for reasons of length are the experts' subjective assessments of the status of media-related teacher education in their respective countries. In the German context, the assessments range from optimism to clear pessimism. An example of an optimistic statement can be found in the interview with expert D0:

"To be honest, an anticipated future leaves me quite optimistic with regards to the question how we can successfully convey media pedagogical skills in higher education to future teachers." (expert D0; own translation)

It is based upon a retrospect view of the increasing spread of practices of advancing media-related educational competencies and of growing chances for preservice teachers to become prepared with the media-related competencies they will need for their professional practice. At the same time, there are also pessimistic statements, such as the following:

"All stakeholders, so to speak, consider the advancement of medienpädagogische Kompetenzen important, it is considered worthy of advancement everywhere and I think there are enough models for the implementation, but the realization is the weak point." (expert D4, own translation)

"At the moment, I would assess the nationwide situation as bad. Simply because there is no systematic advancement of medienpädagogische Kompetenz of preservice teachers. Admittedly, there is no common understanding of media pedagogical advancement." (expert D1, own translation)

Both of these quotations share a criticism towards current practices of advancing media-related educational competencies. The first one acknowledges that important predicaments, such as theoretical models and common awareness, are provided for but attributes a problem to the implementation. The second quotation sees 
inadequate practices of implementation rooted also in an insufficient theory base and understanding. The US experts also took on both positions. For example, a positive statement was expressed by expert US5:

"Given what we are at right now with US education, I think we're doing a solid job.” (expert US5)

This positive confirmation stems from the context of unsatisfying conditions within the US educational system. Hence, the focus of the positive aspect is on the work teacher educators perform against the background of sometimes difficult or inadequate conditions. This opinion is opposed by expert US4 who says:

"I don't think we're doing enough. We're not doing nearly enough. What we're doing is reactive rather than proactive." (expert US4)

A reoccurring motive within the US experts' pessimistic statements corresponds to the quotation from expert US5 emphasizing difficulties within the US educational system, such as in the following:

"Some people really get it, but at the same time, so much of education is structured not to go there, to just basically, control and keep doing what we've always been doing. It's very well designed not to change. That's our experience." (expert US2)

All in all, these positions from Germany and the USA point at local efforts and successful developments, but at the same time they emphasize the long struggle necessary to ensure a comprehensive and systematic inclusion of media-related competencies into teacher education. It also becomes evident, against the background of the previous stakeholder analysis, that experts from both countries attributed difficulties and challenges both to external or contextual factors, such as society and superordinate educational systems, and to internal factors, especially with regards to the community of teacher educators and researchers working on this topic. This interpretation is substantiated in numerous statements. An example connecting these two central issues of systematic challenges and problems emanating from the group of teacher educators can be found in this statement about the German situation:

"The situation is heavily impacted by coincidences. As a preservice teacher, you can be lucky and come across a teacher educator who finds [media pedagogy] interesting and wants to do it. You can also have bad luck [...] and come across someone who completely rejects it, so if I assess this subjectively, it is too random for me and too much dependent on coincidences." (expert D2, own translation). 
This criticism of the group of researchers and teacher educators is also echoed by the German expert D4:

"In [German] media pedagogy, we have maybe not overlooked it, but we have not worked on it intensely and left many questions of teaching and learning with media, if you consider it from a research perspective, to the pedagogic psychology, so you see that many professorships for Mediendidaktik, which should be staffed by media pedagogues, are held by pedagogic psychologists, and I consider this a realization problem." (expert D4, own translation)

In this context, expert US3 even prioritizes the level of teacher educators over systematic and mandatory change:

"Rather than having it come through some policy mandate or dictate, what I would like to see is that teacher educators throughout the country would take up, as part of their professional obligation and service to preservice teachers, to say, "We must be better at teaching media literacy. Therefore, we are going to make time and space in our curriculum to do this in both an explicit way, through one dedicated media literacy course, and also more implicitly, we will thread it throughout the rest of our undergraduate preservice education courses. We're going to do that voluntarily, we're going to do that with intent, and we're going to do that immediately." [...] I don't think that's going to happen right away. Not because people are resistant to it, but because change is hard with everybody, "I've got my class, I've got my assignments. I've got my curriculum, it's already too crowded, I don't have enough time." That is the classic problem in education. Of course, you don't have enough time. We never have enough time. You better start making time for this because if you do not, we are going to be in an even worse situation than we are right now." (expert US3)

The expert interviews also reveal interesting differences between US and German viewpoints on a systemic level with regards to the discipline of what is called Medienpädagogik in Germany. It has been argued before that the German concept of Medienpädagogik can generally be defined as a subdiscipline of educational research. According to the included German literature review, there is a certain consensus to understand teaching with and teaching about media as two key subdomains of Medienpädagogik, even though this duality has been challenged in some cases (e.g., Ruge 2017; Kerres and De Witt 2011; Kerres 2007). Yet all German experts, despite usually having a certain focus on one of these aspects in their work, answered mostly in relation to both fields. In the USA, however, according considerations about the two distinct disciplines of educational technology and media literacy are less common, as has been described by Grafe (2011). The US experts in these interviews strictly 
differentiated between educational technology and media literacy. The ratio of these two main fields and their relevance for initial teacher education across US teacher education programs was described controversially:

"A few years ago, I would have said they're all about the EdTech. Now, I would tell you they're all about media literacy and that the technology is simply a way to gain access to people and access to content." (expert US4)

"Media literacy I feel fairly confident is quite rare in teacher education. Information literacy, digital literacy, some of these other literacies, computer literacy or technology, may be more prevalent as parts of Teacher Ed programs." (expert US6)

Yet the inclusive German perspective was not unheard of by US experts, as the following quotation suggests:

"I think, in the United States, the distinction between media literacy and educational technology is maintained a bit more rigorously, but those ideas [are] certainly like an overlapping Venn diagram, where the circles have a lot of common overlap but are still distinct." (expert US1)

\section{A second expert even criticizes:}

"In the US we see [educational technology and media literacy] as distinct separate spaces, which doesn't make a lot of sense to me." (expert US4)

However, there is also insecurity and anxiety related to a potential fusion of the two disciplines:

"I think my main anxiety is about the conflation of media literacy and educational technology. I worry that [...] media literacy will end up the loser in this distinction." (expert US1)

Consequentially, US experts mostly referred to the background either of media literacy or of educational technology and German experts, while showing a certain tendency or orientation towards one subdomain, related their answers to the superordinate domain of Medienpädagogik. Hence, it can be concluded that there is a certain systemic or disciplinary divergence, which has impacted the experts' views and perspective as well as their evaluations. For example, as concluded in the previous literature review, US educational technology experts had other perceptions of the spread of their subject across teacher education programs, as compared to media literacy experts, which led to differing perceptions on the same question within one group of experts. 
However, it is noteworthy that both German and US experts, and for that matter, both US educational technology and media literacy specialists, pointed out experiences, perspectives and challenges which are surprisingly comparable. According to the experts, the advancement of media-related educational competencies in both countries faces conflicting fields. Centrally, on the one hand, there are systems of teacher education that are largely described as in need of improvement with their requirements, challenges and barriers. On the other hand, there are teacher educators who play a significant role and vary strongly in their engagement, interest and action-taking. With further factors contributing to this tense network of stakeholders, the situation overall appears as heterogeneous, and it becomes evident how complex an endeavor the systematic improvement of respective practices is.

\subsection{Conclusions on Frame Conditions of and Stakeholder Influences on Practices of Advancing Media-related Educational Competencies}

This analysis of stakeholder influences on practices in German and US teacher education, through an initial literature review and a deeper exploration of the expert interviews of stakeholders and frame conditions, allows for extended conclusions on the network of influences. Following the approach of systemizing stakeholders and conditions into levels and dimensions as suggested by related models (e.g., Egetenmeyer, Breitschwerdt, and Lechner 2019; Egetenmeyer and Grafe 2017), the overall results are summarized in Figure 7 by means of a multi-level model. 


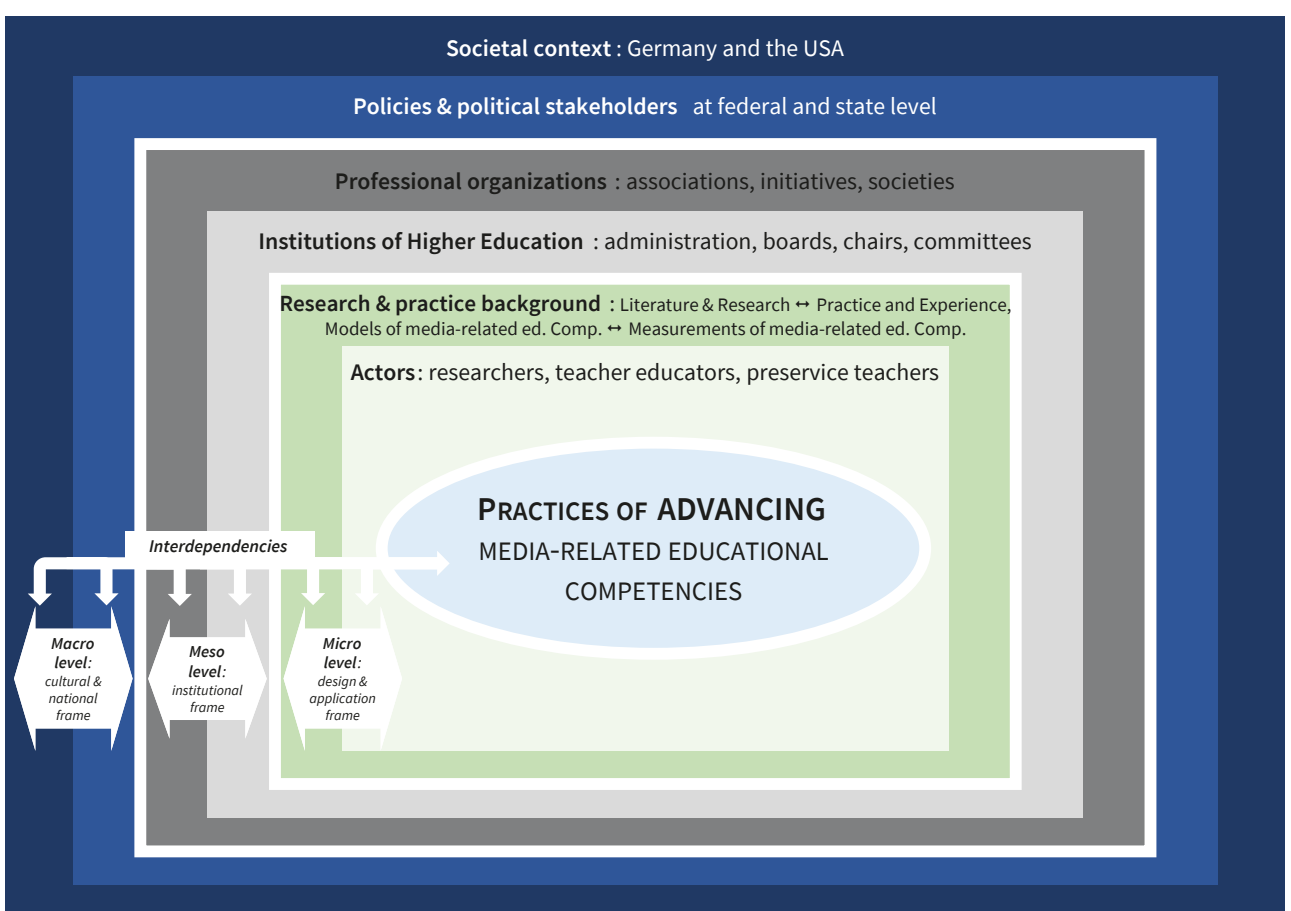

Fig. 7.: Stakeholder influences on practices of advancing media-related educational competencies (own multi-level model).

Figure 7 emphasizes how the various stakeholders and conditions mentioned in the previous chapters shape a framework for all relevant processes in the context of practice in initial teacher education. Stakeholders in this context are understood as persons, groups or organizations with an interest in and an impact on the practices of advancing media-related educational competencies, while conditions refer to non-personal influences that are still closely connected to the stakeholders and practices.

Overall, the stakeholders and conditions are organized on three levels: a macro level, a meso level, and a micro level, with interdependencies between all levels and stakeholder groups, and the practices of advancing media-related educational competencies as the central educational process researched. In accordance with the design of further related multi-level models seeking to analyze influences on educational processes, the three main levels are arranged from general to specific influence (Schrader 2011; Egetenmeyer, Breitschwerdt, and Lechner 2019; Lima, Guimarães, and Touma 2016). There are two stakeholders or influences on each level; they are arranged from a looser to a more binding or direct influence within the level. 


\subsubsection{Macro Level}

Within this arrangement, the macro level provides the general cultural and national frame. On the outer dimension, there is the societal background of Germany and the USA as the two countries focused on in this dissertation. As the international comparative perspective applied reveals, there are national and cultural factors inherent in all dimensions and actions implicitly or explicitly shaping central processes, which is why an international comparative approach is helpful for visualizing and addressing the issue of restrictive viewpoints. In a wider sense, society is affected by all efforts in relation to media-related educational competencies, because it is a central objective of these efforts to enhance and improve initial teacher education to prepare future teachers who can then educate and teach children in appropriate and successful ways to become media-literate and responsible citizens in a digitalized society. To this extent, society and in particular schools, parents and students, but also citizens and employees from other branches, bring about certain expectations for teacher education, for the teachers graduating from it and the competencies they acquire. Hence, an awareness of the contribution and relevance of research on media-related educational competencies for society is vital for responsible and meaningful practices.

The macro level further includes political stakeholders as an inherent part of the national frame (Egetenmeyer, Breitschwerdt, and Lechner 2019). Political stakeholders are particularly indebted to their societal background: they represent and reinforce this background at the same time and are usually expected to act for the public benefit of their country or reference context. In terms of influences on practices of advancing media-related educational competencies, political stakeholders can function on different levels, as there are global, national and state influences. However, the considerations in Chapter 10 clarified that global policies provide a general and hardly binding frame. Policies on a national level both in Germany and the USA play a limited role that is mostly restricted to funding, except for the KMK in Germany with its impactful, but still advisory, resolutions. Apart from this, due to the systems of state sovereignty in educational affairs established in both countries, it is at the state level that policies most directly influence practices in initial teacher education. In both countries, regulations for the final exams of teacher education graduates are a frequently used means for state governments to ensure an obligatory inclusion of media-related topics into initial teacher education. In the US, state-wide standards for teachers are also common, while in Germany, contracts between states and universities are a further way of enforcing influence with respective contents. However, it was revealed in Chapter 10 that these influences and the resulting regulations are heterogeneous and vary between the states in both countries with regards to obligation, shape, inclusion, and results. 


\subsubsection{Meso Level}

In Figure 7, the meso level describes the institutional frame for practices in initial teacher education in Germany and the USA. The outer and thus more general level refers to professional organizations, associations, societies, and initiatives, while the inner level describes the institutions of teacher education with its various interest groups.

Professional organizations often have less of a binding influence and play a rather advisory role, yet they are of major importance. As argued in Chapter 10.3, they provide standards and guidelines that have gained significance in teacher education practices in Germany and the USA. For the German context, it was pointed out that the Division Media Education of the GERA plays a dominant role in this regard, while in the USA the influence is noteworthy, especially of ISTE and SITE in the field of educational technology and of NAMLE in the field of media literacy because of their respective standards, competency models, or core principles. Just like a number of further organizations, these associations also foster dialogue and research and thus help shape the research background on the micro level. They also function as a link to the policy dimension on the macro level because they show strong mutual influences. Resolutions and guidelines from professional organizations specify the research background, which will be discussed in the context of the micro level. They are often supported and used by political stakeholders, as in the case of the ISTE standards, which were also promoted and adopted in state standards by political stakeholders in the US on national and state levels (cf. Chapter 10). At the same time, political actors sometimes also contribute to and constitute organizational and network activities, as described, e.g., in the case of the German D21 network. Hence, the interdependencies between the levels become evident.

The context of the levels of stakeholders and conditions mentioned until now has been rather broad. Decisions made in these contexts, expectations expressed, and input offered usually apply to wider reference frames, such as the whole country or states, or wider target groups. The inner part of the meso level and the micro level, on the other hand, describe the local frame for individual practices of advancing media-related educational competencies in initial teacher education.

On the inner side of the meso level, there are the institutions of higher education, specifically universities. They provide frame conditions for any practices in initial teacher education. As became evident in the expert interviews, influence can be had to varying degrees by administration, boards, chairs, and committees: importantly, the administration interferes on rare occasions only, and boards and committees have a comparable impact especially in US institutions of teacher education. Institutions further shape practices through organizational frame conditions such as leadership style, organizational structures, openness to innovative approaches, and technical equipment. These frame conditions also depend on stakeholders from the 
meso and macro level in terms of regulations and obligations, e.g., for the design of study programs and exams. In the US context, there is a further influence of other institutions with a good reputation. US experts described to orientate themselves towards practices at well-known universities in some cases. Such orientations are less common in Germany, given the less hierarchical structure of German institutions of higher education.

\subsubsection{Micro Level}

The micro level describes the design and application frame and is thus specific to unique practices in teacher education at one place. The outer micro level consists of the research and practice background as a central condition. It includes literature and research relevant for respective practices of advancing media-related educational competencies, but also established practices and related experiences serving as an orientation and reference for the stakeholders on the inner dimension. This also comprises references in literature to, and experiences with, models and measurements of media-related educational competencies, as discussed in Parts I and II of this dissertation.

As became evident, especially in the expert interviews (cf. Chapter 11), the advancement of media-related educational competencies in Germany and the USA is oriented towards frameworks and sources with a certain focus on national references. For example, teacher educators in Germany described using the $\mathrm{M}^{3} \mathrm{~K}$ framework as a reference for systemizing study offers in the field of Medienpädagogik, and they repeatedly pointed out the relevance of further national sources such as the works of Blömeke and Tulodziecki for their media pedagogical work. In the US, however, experts primarily built on the US research background, mentioning and sometimes critically discussing, for example, the TPACK model or the ISTE standards. To this extent, there is an evident connection between the dimensions of competency modeling and advancing competencies, which will be addressed in the concluding chapter in greater detail. In the context of the multi-level model of stakeholder influences, it is important to acknowledge that the research and experience background shapes an overall background for actors to refer to.

Actors form the most inner part of the multi-level model and comprise persons directly involved in and affected by practices of advancing media-related educational competencies. This specifically refers to researchers and teacher educators and to preservice teachers as recipients. It has been argued above that there are differences between the USA and Germany in regard to the role of preservice teachers. The influence German preservice teachers can have on their own media-related education is higher due to more autonomy in the design of individual study curricula, which brings about a certain responsibility that US preservice teachers have in fewer cases. 
As the experts in the study presented in Part III emphasized, teacher educators are a key stakeholder in the advancement of media-related educational competencies with preservice teachers. Influenced by the overall context on the macro level, indebted to the regulations and other impacts from the micro and meso levels, and dependent on the frame conditions formulated by their respective institutions, teacher educators yet have a certain amount of individual flexibility to realize the advancement of media-related educational competencies with their preservice teachers in unique ways. Within the restrictions given, they can put emphasis on certain contents and neglect others and thus are of core importance for this context. The responsibility coming along with this role is even enhanced in the increasing realization of the technology infusion approach in the US suggested, e.g., by Wetzel, Buss, Foulger, and Lindsey (2014) or Foulger et al. (2019). In the case of classical distinct educational technology or media literacy courses, there is a structural responsibility for the institutions to organize, integrate and offer such courses. To a certain degree, the technology infusion approach shifts the responsibility for the media-related education of preservice teachers to the teacher educators of courses that are not inherently media-focused. This responsibility brings about a considerable challenge for teacher educators to develop the respective necessary competencies on their own (Foulger et al. 2017; cf. Chapter 4.2), but it also brings about an advantageous spread of educational technology and media literacy across topics and contents.

All in all, the analysis of stakeholders and frame conditions impacting practices of advancing media-related educational competencies in initial teacher education in the USA and Germany paints a picture of a dense network of interests and influences. The interdependencies between the levels are often mutual and subject to multifold individual conditions, so that the representation presented in the multi-level model is necessarily abstract and generalized. However, it becomes evident that the advancement of media-related educational competencies is a complex issue. It has been pointed out in Chapter 9, in the context of current practices, that research sources both from the USA and from Germany criticize current practices in this context from multiple angles. The overview provided in this chapter now adds to this discussion a systematization of conditions and influences and thus illustrates interdependencies and parameters that can and need to be considered and addressed in the ongoing improvement of respective practices. 


\section{References}

Ackeren, I. van, S. Aufenanger, B. Eickelmann, S. Friedrich, R. Kammerl, J. Knopf, K. Mayrberger, H. Scheika, K. Scheiter, and M. Schiefner-Rohs. 2019. "Digitalisierung in Der Lehrerbildung. Herausforderungen, Entwicklungsfelder Und Förderung von Gesamtkonzepten.” DDS - Die Deutsche Schule 111 (1): 103-19. https://doi.org/10.31244/dds.2019.01.10.

American Association of Colleges of Teacher Education [AACTE], and Partnership for 21st Century Skills [P21]. 2010. "21st Century Knowledge and Skills in Educator Preparation." Pearson. https://files.eric.ed.gov/fulltext/ ED519336.pdf.

Aufenanger, S. 2014. "Medienpädagogik in Der Lehrerbildung Der Universität Mainz." In Grundbildung Medien in Pädagogischen Studiengängen, edited by P. Imort and H. Niesyto, 53-64. München, Germany: kopaed.

Bakir, N. 2016. "Technology and Teacher Education: A Brief Glimpse of the Research and Practice That Have Shaped the Field." TechTrends 60 (1): 21-29. https://doi.org/10.1007/ s11528-015-0013-4.

Baumann, D., and B. Read. 2018. "A Brief History of GOP Attempts to Kill the Education Dept." The Chronicle of Higher Education, June 21, 2018. https://www.chronicle.com/article/ABrief-History-of-GOP/243739.

Bayerische Staatskanzlei. 2017. "Bayern Digital II. Investitionsprogramm Für Die Digitale Zukunft Bayerns.” Presentation slides, May 29. http://www.bayern.de/wp-content/uploads/2014/09/17-05-30-masterplan-bayern-digital_massnahmen_anlage-mrv_final.pdf.

Beach, R., and F. W. Baker. 2011. "Why Core Standards Must Embrace Media Literacy [Commentary]." Education Week 36 (30). https://www.edweek.org/ew/ articles/2011/06/22/36baker. h30.html?print=1.

Belland, B. R. 2009. "Using the Theory of Habitus to Move beyond the Study of Barriers to Technology Integration." Computers \& Education 52 (2): 353-64. https://doi.org/10.1016/j. compedu.2008.09.004.

Bertelsmann Stiftung, CHE Centrum für Hochschulentwicklung gGmbH, Deutsche Telekom Stiftung, and Stifterverband für die Deutsche Wissenschaft, eds. 2018. Lehramtsstudium in Der Digitalen Welt - Professionelle Vorbereitung Auf Den Unterricht Mit Digitalen Medien?! Gütersloh, Germany: Monitor Lehrerbildung.

Blömeke, S. 2000. Medienpädagogische Kompetenz: theoretische und empirische Fundierung eines zentralen Elements der Lehrerausbildung. München, Germany: kopaed.

Blömeke. 2003. "Neue Medien in Der Lehrerausbildung. Zu Angemessenen (Und Unangemessenen) Zielen Und Inhalten Des Lehramtsstudiums." MedienPädagogik: Zeitschrift Für Theorie Und Praxis Der Medienbildung 3: 1-29.

Blömeke. 2009. "The Impact of Global Tendencies on the German Teacher Education System." In Reforming Teaching Globally, edited by M. T. Tatto, 55-76. Charlotte, NC: Information Age. 
Blömeke, S., J. -E. Gustafsson, and R. J. Shavelson. 2015. "Beyond Dichotomies: Competence Viewed as a Continuum." Zeitschrift Für Psychologie 223 (1): 3-13. https://doi. org/10.1027/2151-2604/a000194.

Blömeke, S., and L. Paine. 2008. "Getting the Fish out of the Water: Considering Benefits and Problems of Doing Research on Teacher Education at an International Level." Teaching and Teacher Education 24 (8): 2027-37. https://doi.org/10.1016/j.tate.2008.05.006.

Blömeke, S., O. Zlatkin-Troitschanskaia, C. Kuhn, and J. Fege, eds. 2013. Modeling and Measuring Competencies in Higher Education. Tasks and Challenges. Rotterdam, Netherlands: Sense Publishers.

Bogner, A., B. Littig, and W. Menz, eds. 2009. Interviewing Experts. Research Methods Series. London, England: Palgrave Macmillan.

Bogner, A., B. Littig, and W. Menz. 2014. Interviews mit Experten. Eine praxisorientierte Einführung. Qualitative Sozialforschung. Wiesbaden, Germany: Springer VS.

Brautmeier, M. 2013. "Die Zukunft Des Bildungsföderalismus in Deutschland.” Doctoral dissertation, Berlin, Germany: Freie Universität Berlin. https://d-nb.info/1045604275/34.

Bremer, C. 2011a. "Medienkompetenz in Der Hessischen Lehrerbildung." In Framediale - Digitale Medien in Bildungseinrichtungen, edited by T. Knaus and O. Engel, 57-73. München, Germany: kopaed.

Brenner, M. E. 2006. "Interviewing in Educational Research." In Handbook of Complementary Methods in Education Research, edited by J. L. Green, G. Camilli, and P. B. Elmore, 357-70. Mahwah, NJ: Lawrence Erlbaum Associates.

Brümmer, F., A. Durdel, C. Fischer-Münnich, J. Fittkau, W. Weiger, and H. Altrichter. 2018. Qualitätsoffensive Lehrerbildung. Zwischenbericht Der Evaluation. Hamburg, Germany: Ramboll Management Consulting. https://de.ramboll.com/media/rde/2018_qlb_zwischenbericht.

Bundesministerium für Forschung und Bildung [BMBF]. 2010. "Kompetenzen in Einer Digital Geprägten Kultur. Medienbildung Für Die Persönlichkeitsentwicklung, Für Die Gesellschaftliche Teilhabe Und Für Die Entwicklung von Ausbildungs- Und Erwerbsfähigkeit." Bonn, Germany: BMBF. https://www.dlr.de/pt/Portaldata/45/Resources/a_dokumente/bildungsforschung/Medienbildung_Broschuere_2010.pdf.

Bundesministerium für Forschung und Bildung [BMBF]. 2016. Neue Wege in Der Lehrerbildung. Die Qualitätsoffensive Lehrerbildung. Berlin, Germany: BMBF. https://www.qualitaetsoffensive-lehrerbildung.de/files/Neue_Wege_in_der_Lehrerbildung.pdf.

Bundesministerium für Forschung und Bildung [BMBF]. 2019. "Forschung Zur Digitalen Hochschulbildung." https://www.wihoforschung.de/de/zweite-foerderlinie-zur-digitalen-hochschulbildung-2382.php.

Bundesverband Deutscher Stiftungen. n.d. "Liste Der Größten Gemeinwohlorientierten Stiftungen.” Berlin, Germany. https://www.stiftungen.org/de/stiftungen/ zahlen-und-daten/liste-der-groessten-stiftungen.html.

Center for Media Literacy [CML]. n.d. "A New Climate for Professional Development in Media Literacy." https://www.medialit.org/new-climate-professional-development-media-literacy. 
Cisneros, C. R. 2019. "Senate Bill 194. School Media Literacy Program.” https://legiscan.com/ NM/text/SB194/2019.

Collins, H. M., and R. Evans. 2007. Rethinking Expertise. Chicago, IL: University of Chicago Press.

Common Core State Standards Initiative. n.d. "Common Core State Standards for English Language Arts \& Literacy in History/Social Studies, Science, and Technical Subjects." http:// www.corestandards.org/wp-content/uploads/ELA_Standards1.pdf.

Common Core State Standards Initiative. 2019. "Common Core State Standards." http://www. corestandards.org/.

Connecticut State Department of Administrative Services. 2019. "Connecticut Commission for Educational Technology." https://portal.ct.gov/DAS/CTEdTech/ Commission-for-Educational-Technology.

Cooper Moore, D., and E. Bonilla. 2014. Media Literacy Education \& The Common Core State Standards. S.1: NAMLE. https://namle.net/wp-content/uploads/2015/04/ namlemleccssguide.pdf.

Council for the Accreditation of Educator Preparation [CAEP]. 2019. "2013 CAEP Standards." Washington, D.C. http://caepnet.org/ /media/Files/caep/ standards/caep-standards-onepager-0219.pdf?la=en.

Culver, S. H., and T. Redmond. 2019. Media Literacy Snapshot. New York, NY: National Association for Media Literacy Education. https://namle.net/wp-content/uploads/2019/06/ SOML_FINAL.pdf.

Davis, N. 2003. "Technology in Teacher Education in the USA: What Makes for Sustainable Good Practice?" Technology, Pedagogy and Education 12 (1): 59-84. https://doi. org/10.1080/14759390300200146.

Deutsche Gesellschaft für Erziehungswissenschaft [DGfE]. n.d. “About DGfE (GERA).” https:// www.dgfe.de/en/about-dgfe-gera.html.

Deutsche Telekom Stiftung. 2019. "Wissen, Was in Zukunft Zählt. Impulsgeber Für Ein Neues Bildungs-Ökosystem.” Bonn, Germany. https://www.telekom-stiftung.de/stiftung.

Deutscher Bundestag. 2018. "Grundgesetzänderung Soll Mehr Investitionen in Bildung Ermöglichen.” Berlin, Germany. https://www.bundestag.de/dokumente/ textarchiv/2018/ kw39-de-aenderung-gg-bildung-bau-verkehr-568946.

Egetenmeyer, R., L. Breitschwerdt, and R. Lechner. 2019. “From 'Traditional Professions' to 'New Professionalism': A Multi-Level Perspective for Analysing Professionalisation in Adult and Continuing Education." Journal of Adult and Continuing Education 25 (1): 7-24. https:// doi.org/10.1177/1477971418814009.

Egetenmeyer, R., and S. Grafe. 2017. "Digitalisierung in Der Erwachsenenbildung Und in Der Beruflichen Weiterbildung." Unpublished BMBF project proposal in the program ,Digitalisierung im Bildungsbereich‘. Würzburg, Germany: Julius-Maximilians-Universität.

Engbring, D. 2018. "Überlegungen Zu Einem Beitrag Zur Lehrerbildung in Der Digital Vernetzten Welt. Ein Auf Erfahrungen Gestützter Bericht Und Diskussionsbeitrag." In Informatik Und Medien - 8. Münsteraner Workshop Zur Schulinformatik, edited by M. Thomas and M. Weigend, 95-106. Norderstedt, Germany: Books on Demand. 
Enochsson, A., and C. Rizza. 2009. "ICT in Initial Teacher Training: Research Review." OECD Education Working Papers 38. Vol. 38. OECD Education Working Papers. https://doi. org/10.1787/220502872611.

Ertmer, P. A., and A. T. Ottenbreit-Leftwich. 2010. "Teacher Technology Change: How Knowledge, Confidence, Beliefs, and Culture Intersect." Journal of Research on Technology in Education 42 (3): 255-84. https://doi.org/10.1080/15391523.2010.10782551.

Fedorov, A., A. Levitskava, and E. Camarero. 2016. "Curricula for Media Literacy Education According to International Experts." European Journal of Contemporary Education 17 (3): 324-34. https://doi.org/10.13187/ejced.2016.17.324.

Fleischer, J., K. Koeppen, M. Kenk, E. Klieme, and D. Leutner. 2013. “Kompetenzmodellierung: Struktur, Konzepte Und Forschungszugänge Des DFG-Schwerpunktprogramms.” Zeitschrift Für Erziehungswissenschaft 16: 5-22.

Flick, U., E. Kardoff, and I. Steinke, eds. 2004. A Companion to Qualitative Research. London, England: Sage.

Flores-Koulish, S. A. 2006. "Media Literacy: An Entrée for Pre-service Teachers into Critical Pedagogy." Teaching Education 17 (3): 239-49. https://doi.org/10.1080/10476210600849706.

Flores-Koulish, S. A., and D. Deal. 2008. "Reacting to Change: Critical Media Literacy for United States Reading Teachers?" SIMILE: Studies In Media \& Information Literacy Education 8 (3): 1-14. https://doi.org/10.3138/sim.8.3.001.

Flores-Koulish, S. A., D. Deal, J. Losinger, K. McCarthy, and E. Rosebrugh. 2011. "After the Media Literacy Course: Three Early Childhood Teachers Look Back." Action in Teacher Education 33 (2): 127-43. https://doi.org/10.1080/01626620.2011.569308.

Foulger, T., K. J. Graziano, D. A. Schmidt-Crawford, and D. A. Slykhuis. 2017. "Teacher Educator Technology Competencies.” Journal of Technology and Teacher Education 25 (4): 413-48.

Foulger, T., K. Wetzel, and R. R. Buss. 2019. "Moving Toward a Technology Infusion Approach: Considerations for Teacher Preparation Programs." Journal of Digital Learning in Teacher Education 35 (2): 79-91. https://doi.org/10.1080/21532974.2019.1568325.

From, J. 2017. "Pedagogical Digital Competence-Between Values, Knowledge and Skills." Higher Education Studies 7 (2): 43-50. https://doi.org/10.5539/hes.v7n2p43.

Fusch, P. I., and L. R. Ness. 2015. "Are We There Yet? Data Saturastion in Qualitative Research." The Qualitative Report 20 (9): 1408-16.

General Court of the Commonwealth of Massachusetts. 2017. "Senate Bill No. 2128. An Act Relative to Healthy Youth." https://malegislature.gov/Bills/190/S2128.

Gesellschaft für Fachdidaktik e.V. [GFD]. 2018. "Fachliche Bildung in Der Digitalen Welt. Positionspapier Der Gesellschaft Für Fachdidaktik.” Position paper. http://www.fachdidaktik. org/wp-content/uploads/2018/07/GFD-Positionspapier-Fachliche-Bildung-in-der-digitalen-Welt-2018-FINAL-HP-Version.pdf.

Gesellschaft für Medien in der Wissenschaft e.V. [GMW]. 2019. "Gesellschaft Für Medien in Der Wissenschaft.” Dresden, Germany. https://www.gmw-online.de/. 
Gesellschaft für Medienpädagogik und Kommunikationskultur [GMK]. n.d. "About GMK." Bielefeld, Germany. https://www.gmk-net.de/about-gmk/.

Gesellschaft für Medienpädagogik und Kommunikationskultur [GMK], \& Keine Bildung ohne Medien [KBOM]. 2014. "Medienbildung = IT-Förderung? Stellungnahme Der Initiative “Keine Bildung Ohne Medien!” Und Der GMK Zum Berliner Koalitionsvertrag." Position paper. Bielefeld, Germany. http://www.kultur-bildet.de/sites/default/files/mediapool/glossar/pdf/medienbildung_koalitionsvertrag.pdf.

Goertz, L., and B. Baeßler. 2018. "Überblicksstudie Zum Thema Digitalisierung in Der Lehrerbildung. Überblicksstudie Zu Elf Ausgewählten Fallbeispielen. Arbeitspapier Nr. 36." Berlin, Germany: Hochschulforum Digitalisierung beim Stifterverband für die Deutsche Wissenschaft. https://hochschulforumdigitalisierung.de/sites/ default/files/dateien/HFD_ AP_Nr36_Ueberblicksstudie_Digitalisierung_Lehrerbildung.pdf.

Goetze, S. K., D. S. Brown, and G. Schwarz. 2005. “Teachers Need Media Literacy, Too!” Media Literacy: Transforming Curriculum and Teaching. The 104th Yearbook of the National Society for the Study of Education 104 (1): 161-79. https://doi.org/10.1111/j.1744-7984.2005.00010.x.

GovTrack.us. 2017. "H.R. 899 - 115th Congress: To Terminate the Department of Education." 2017. https://www.govtrack.us/congress/bills/115/hr899/summary.

GovTrack.us. 2019. "H.R. 899 - 116th Congress: To Terminate the Department of Education." 2019. https://www.govtrack.us/congress/bills/116/hr899.

Grafe, S. 2011. “'Media Literacy' Und 'Media (Literacy) Education' in Den USA: Ein Brückenschlag Über Den Atlantik." MedienPädagogik 20 (September 13): 59-80.

Graham, C. R. 2011. "Theoretical Considerations for Understanding Technological Pedagogical Content Knowledge (TPACK).” Computers \& Education 57 (3): 1953-60. https://doi. org/10.1016/j.compedu.2011.04.010.

Green, E. L. 2017. "Trump Orders Review of Education Policies to Strengthen Local Control." The New York Times, April 26, 2017. https://www.nytimes.com/2017/04/26/us/ politics/ trump-education-policy-review.html.

Gretter, S., and A. Yadav. 2018. "What Do Preservice Teachers Think about Teaching Media Literacy? An Exploratory Study Using the Theory of Planned Behavior." Journal of Media Literacy Education 10 (1): 104-23. https://doi.org/10.23860/JMLE-2018-10-1-6.

Gronseth, S., T. Brush, A. Ottenbreit-Leftwich, J. Strycker, S. Abaci, W. Easterling, T. Roman, S. Shin, and P. van Leusen. 2010. "Equipping the Next Generation of Teachers: Technology Preparation and Practice." Journal of Digital Learning in Teacher Education 27 (1): 30-36. https://doi.org/10.1080/21532974.2010.10784654.

Hauf-Tulodziecki, A. 1999. "Informatische Bildung Und Medienerziehung." In Informatik Und Schule. Informatik Aktuell, edited by A. Schwill, 121-29. Berlin, Germany: Springer.

Hepp, G. 2013. “Wie Der Staat Das Bildungswesen Prägt.” Bundeszentrale Für Politische Bildung, September. http://www.bpb.de/gesellschaft/kultur/zukunft-bildung/145238/staat-als-akteur?p=all. 
Herzig, B. 2016. "Medienbildung Und Informatische Bildung - Interdisziplinäre Spurensuche." MedienPädagogik: Zeitschrift Für Theorie Und Praxis Der Medienbildung 25 (October 28): 59-79. https://doi.org/10.21240/mpaed/25/2016.10.28.X.

Herzig, B., S. Aßmann, and T. -M. Klar. 2014. "Grundbildung Medien Im Profilstudium Im Lehramt." In Grundbildung Medien in Pädagogischen Studiengängen, edited by P. Imort and H. Niesyto, 65-80. München, Germany: kopaed.

Herzig, B., A. Martin, N. Schaper, and D. Ossenschmidt. 2015. "Modellierung Und Messung Medienpädagogischer Kompetenz - Grundlagen Und Erste Ergebnisse." In Kompetenzerwerb an Hochschulen: Modellierung Und Messung. Zur Professionalisierung Angehender Lehrerinnen Und Lehrer Sowie Frühpädagogischer Fachkräfte, edited by B. Koch-Priewe, A. Köker, J. Seifried, and E. Wuttke, 153-76. Bad Heilbrunn, Germany: Klinkhardt.

Hessisches Kultusministerium. 2017. "Amtsblatt Des Hessischen Kultusministeriums." Official journal. Nürnberg, Germany: menthamedia. https://hessisches-amtsblatt.de/wp-content/plugins/pdf-viewer/stable/web/viewer.html?file=/wp-content/uploads/online_pdf/ pdf_2017/03_2017.pdf.

Hobbs, R. 2010. "Digital and Media Literacy: A Plan of Action. A White Paper on the Digital and Media Literacy Recommendations of the Knight Commission on the Information Needs of Communities in a Democracy." Washington, D.C.: The Aspen Institute. https://www.knightfoundation.org/media/uploads/publication_pdfs/ Digital_and_Media_Literacy_A_Plan_ of_Action.pdf.

Hur, J. W., T. Cullen, and T. Brush. 2010. "Teaching for Application: A Model for Assisting Preservice Teachers with Technology Integration." Journal of Technology and Teacher Education 18 (1): 161-82.

Imort, P., and H. Niesyto, eds. 2014. Grundbildung Medien in Pädagogischen Studiengängen. Vol. 10. Medienpädagogik Interdisziplinär. München, Germany: kopaed.

Initiative D21 e.V. 2019. "Über Uns. Initiative D21 - Deutschlands Größtes Gemeinnütziges Netzwerk Für Die Digitale Gesellschaft.” Berlin, Germany. https://initiatived21.de/uberuns/.

International Society for Technology in Education [ISTE]. n.d. "ISTE Standards." https://www. iste.org/standards.

International Society for Technology in Education [ISTE]. 2017. "ISTE Standards for Educators." https://www.iste.org/standards/for-educators.

JFF - Institut für Medienpädagogik. 2018. “JFF - Institut Für Medienpädagogik.” München, Germany. https://www.jff.de.

Kaiser, R. 2014. Qualitative Experteninterviews. Konzeptionelle Grundlagen und praktische Durchführung. Wiesbaden, Germany: Springer VS. https://doi.org/10.1007/978-3-65802479-6.

Kammerl, R., and K. Mayrberger. 2011. "Medienpädagogik in Der Lehrerinnen- Und Lehrerbildung in Deutschland: Aktuelle Situation Und Desiderata." Beiträge Zur Lehrerinnen- Und Lehrerbildung 29 (2): 172-84. 
Kammerl, R., and K. Mayrberger. 2014. "Medienpädagogik in Der Lehrerbildung. Zum Status Quo Dreier Standorte in Verschiedenen Deutschen Bundesländern.” In Grundbildung Medien in Pädagogischen Studiengängen, edited by P. Imort and H. Niesyto, 81-93. München, Germany: kopaed.

Kerres, M. 2007. "Zum Selbstverständnis Der Mediendidaktik - Eine Gestaltungsdisziplin Innerhalb Der Medienpädagogik?” In Jahrbuch MedienPädagogik 6, edited by W. Sesink, M. Kerres, and H. Moser, 161-78. Wiesbaden, Germany: VS Verlag für Sozialwissenschaften.

Kerres, M., and C. De Witt. 2011. "Zur (Neu)Positionierung Der Mediendidaktik. Handlungs- Und Gestaltungsorientierung in Der Medienpädagogik.” MedienPädagogik: Zeitschrift Für Theorie Und Praxis Der Medienbildung 20 (September 23): 259-70. https://doi.org/10.21240/ mpaed/20/2011.09.23.X.

Kleiner, B., N. Thomas, N. Lewis, and B. Greene. 2007. "Educational Technology in Teacher Education Programs for Initial Licensure." Statistical analysis report. Washington, D.C.: National Center for Education Statistics, Institute of Education Sciences, U.S. Department of Education. https://nces.ed.gov/pubs2008/ 2008040.pdf.

Kohlbacher, F. 2006. "The Use of Qualitative Content Analysis in Case Study Research." Forum Qualitative Sozialforschung/Forum: Qualitative Social Research 7 (1): 1-30.

Kommer, S. 2019. "Keine Bildung Ohne Medien.” 2019. https://www.keine-bildung-ohne-medien.de/.

Kotthoff, H. -G., and E. Terhart. 2013. "'New' Solutions to 'Old' Problems? Recent Reforms in Teacher Education in Germany.” Revista Española de Educación Comparada 22: 73-92.

Krueger, R. A., and M. A. Casey. 2015. Focus Groups: A Practical Guide for Applied Research. 5th ed. Los Angeles, CA: Sage.

Krumsvik, R. J. 2012. "Teacher Educators' Digital Competence." Scandinavian Journal of Educational Research 58 (3): 269-80.

Krumsvik, R. J. 2014. "Teacher Educators' Digital Competence." Scandinavian Journal of Educational Research 58 (3): 269-80. https://doi.org/10.1080/00313831.2012.726273.

Kultusministerkonferenz [KMK]. 1986. "Neue Medien Und Technologien in Der Schule." Bonn, Germany: Sekretariat der KMK.

Kultusministerkonferenz [KMK]. 1995. "Medienpädagogik in Der Schule. Erklärung Der Kultusministerkonferenz Vom 12.05.1995." Bonn, Germany: Sekretariat der KMK.

Kultusministerkonferenz [KMK]. 1997. "Neue Medien Und Telekommunikation Im Bildungswesen. Beschluss Der Kultusministerkonferenz Vom 28. Februar 1997.” Berlin, Germany: Sekretariat der KMK.

Kultusministerkonferenz [KMK]. 1998. "Zur Rolle Der Medienpädagogik, Insbesondere Der Neuen Medien Und Der Telekommunikation in Der Lehrerbildung. Bericht Des Schulausschusses Vom 11.12.1998." http://www.kmk.org/fileadmin/ Dateien/pdf/PresseUndAktuelles/Beschluesse_Veroeffentlichungen/neuemed.pdf. 
Kultusministerkonferenz [KMK]. 2004. "Standards Für Die Lehrerbildung: Bildungswissenschaften. Beschluss Der Kultusministerkonferenz Vom 16.12.2004." Berlin, Germany: Sekretariat der KMK. https://www.kmk.org/fileadmin/Dateien/veroeffentlichungen_beschluesse/2004/2004_12_16-Standards-Lehrerbildung.pdf.

Kultusministerkonferenz [KMK]. 2005. Bildungsstandards Der Kultusministerkonferenz. Erläuterung Zur Konzeption Und Entwicklung. München, Germany: Wolters Kluwer. https:// www.kmk.org/fileadmin/veroeffentlichungen_beschluesse/2004/2004_12_16-Bildungsstandards-Konzeption-Entwicklung.pdf.

Kultusministerkonferenz [KMK]. 2012. "Medienbildung in Der Schule. Beschluss Der Kultusministerkonferenz Vom 8. März 2012.” http://www.kmk.org/fileadmin/Dateien/veroeffentlichungen_beschluesse/2012/2012_03_08_Medienbildung.pdf.

Kultusministerkonferenz [KMK]. 2016. "Strategie Der Kultusministerkonferenz "Bildung in Der Digitalen Welt." Beschluss Der Kultusministerkonferenz Vom 08.12.2016 in Der Fassung Vom 07.12.2017." Berlin, Germany: Sekretariat der Kultusministerkonferenz. https://www. kmk.org/fileadmin/Dateien/pdf/PresseUndAktuelles/2018/Digitalstrategie_2017_mit_ Weiterbildung.pdf.

Lima, L. C., P. Guimarães, and N. Touma. 2016. "Adult Learning and Education Policies in Germany, Portugal and Sweden: An Analysis of National Reports to CONFINEA VI." In Adult Education and Lifelong Learning in Europe and beyond. Comparative Perspectives from the 2015 Würzburg Winter School, edited by R. Egetenmeyer, 28-66. Frankfurt a. M., Germany: Peter Lang.

Mayrberger, K., and S. Kumar. 2014. "Mediendidaktik Und Educational Technology. Zwei Perspektiven Auf Die Gestaltung von Lernumgebungen Mit Digitalen Medien.” In Lernräume Gestalten - Bildungskontexte Vielfältig Denken, edited by K. Rummler, 67:44-55. Medien in Der Wissenschaft. Münster, Germany: Waxmann.

Mayring, P. 2015. Qualitative Inhaltsanalyse: Grundlagen und Techniken. 12th ed. Weinheim, Germany: Beltz.

Meehan, J., B. Ray, A. Walker, S. Wells, and G. Schwarz. 2015. "Media Literacy in Teacher Education: A Good Fit across the Curriculum." Journal of Media Literacy Education 7 (2): 81-86.

Milken Exchange on Education Technology. 1999. Will New Teachers Be Prepared to Teach in a Digital Age? A National Survey on Information Technology in Teacher Education. Santa Monica, CA: Milken Exchange on Education Technology. https://files.eric.ed.gov/fulltext/ ED428072.pdf.

Mishra, P., and M. J. Koehler. 2006. "Technological Pedagogical Content Knowledge: A Framework for Integrating Technology in Teacher's Knowledge.” Teachers College Record 108 (6): 1017-54. https://doi.org/10.1111/j.1467-9620.2006.00684.x.

MissouriState. n.d. "Missouri Teacher Standards Alignment with InTASC and ISTE Standards." https://www.missouristate.edu/assets/caep/1-1-1_Standards Alignment.pdf.

National Association for Media Literacy Education [NAMLE]. n.d. "National Association for Media Literacy Education." https://namle.net/about/. 
National Association for Media Literacy Education [NAMLE]. 2007. "The Core Principles of Media Literacy Education." https://namle.net/publications/core-principles/.

Netzwerk Digitale Bildung. n.d. "Mission Statement." n.d. https://www.netzwerk-digitale-bildung.de/das-netzwerk/mission-statement/.

Niesyto, H. 2014. "Grundbildung Medien an Der Pädagogischen Hochschule Ludwigsburg." In Grundbildung Medien in Pädagogischen Studiengängen, edited by P. Imort and H. Niesyto, 125-38. München, Germany: kopaed.

Oliver, K., and L. Townsend. 2013. "Preparing Teachers for Technology Integration: Programs, Competencies, and Factors from the Literature." National Teacher Education Journal 6 (3): 41-60.

Pettersson, F. 2018. "On the Issues of Digital Competence in Educational Contexts - a Review of Literature." Education and Information Technologies 23 (3): 1005-21. https://doi. org/10.1007/s10639-017-9649-3.

Pleimfeldner, M. 2017. "Das Portfolio Medienbildungskompetenz Als Bestandteil Der Lehrerbildung in Hessen." http://medien.bildung. hessen.de/pomebiko/index.html.

Polly, D., C. Mims, C. E. Shepherd, and F. Inan. 2010. "Evidence of Impact: Transforming Teacher Education with Preparing Tomorrow's Teachers to Teach with Technology (PT3) Grants." Teaching and Teacher Education 26 (4): 863-70. https://doi.org/10.1016/j.tate.2009.10.024.

Post, P. E. 2004. "Ohio Develops Technology Academic Content Standards." The Technology Teacher, June, 25-29.

Przyborski, A., and M. Wohlrab-Sahr. 2014. Qualitative Sozialforschung. Ein Arbeitsbuch. 4th ed. München, Germany: Oldenbourg Wissenschaftsverlag. https://doi. org/10.1524/9783486719550.

Randles, J. 2017. "Educator Standards Make Their Way into Texas Law." ISTE, July 26, 2017. https://www.iste.org/explore/ISTE-blog/Educator-Standards-make-their-way-into-Texas-law? articleid=1029.

Redecker, C. 2017. "European Framework for the Digital Competence of Educators: DigCompEdu." Luxembourg, Luxembourg: Publications Office of the European Union. https://doi. $\operatorname{org} / 10.2760 / 159770$.

Redmond, T. 2016. "Learning to Teach the Media: Preservice Teachers Articulate the Value of Media Literacy Education." In Handbook of Research on Media Literacy in the Digital Age, edited by M. N. Yildiz and J. Keengwe, 31-52. Hershey, PA: Information Science Reference. https://doi.org/10.4018/978-1-4666-9667-9.ch002.

Reiter, A. 2010. "Medienbildung Auf Der Überholspur. Ein Ersatz Für Die Informatische Bildung?" In 25 Jahre Schulinformatik in Österreich. Zukunft Mit Herkunft. Tagungsband 271, edited by G. Brandhofer, 74-99. Wien, Austria: Österreichische Computer Gesellschaft.

Riegel, C., and Y. Tong. 2017. "Educational Technology and Teacher Education Programs: A Geographic Information Systems Study." Teacher Education and Practice 30 (4): 662-83.

Ruge, W. B. 2017. "Undisziplinierte Pluralität. Anmerkungen Zu Einer Wissenschaftstheorie Der Medienpädagogik." MedienPädagogik: Zeitschrift Für Theorie Und Praxis Der Medienbildung 27 (April 4): 100-120. https://doi.org/10.21240/mpaed/27/2017.04.04.X. 
Sampson, D., and D. Fytros. 2008. "Competence Models in Technology-Enhanced Competence-Based Learning." In Handbook on Information Technologies for Education and Training, edited by H. H. Adelsberger, Kinshuk, J. M. Pawlowski, and D. G. Sampson, 155-77. Berlin, Heidelberg: Springer. https://doi.org/10.1007/978-3-540-74155-8_9.

Sang, G., M. Valcke, J. van Braak, and J. Tondeur. 2010. "Student Teachers' Thinking Processes and ICT Integration: Predictors of Prospective Teaching Behaviors with Educational Technology." Computers \& Education 54 (1): 103-12. https://doi.org/10.1016/j.compedu.2009.07.010.

Schiefner-Rohs, M. 2012. "Verankerung von medienpädagogischer Kompetenz in der universitären Lehrerbildung." In Jahrbuch Medienpädagogik 9, edited by R. Schulz-Zander, B. Eickelmann, H. Moser, H. Niesyto, and P. Grell, 359-87. Wiesbaden, Germany: VS Verlag für Sozialwissenschaften. https://doi.org/10.1007/978-3-531-94219-3_16.

Schmid, U., L. Goertz, S. Radomski, S. Thom, and J. Behrens. 2017. "Monitor Digitale Bildung. \#2 Die Hochschulen Im Digitalen Zeitalter.” Gütersloh, Germany: Bertelsmann Stiftung. https://www.bertelsmann-stiftung.de/fileadmin/files/BSt/ Publikationen/GrauePublikationen/DigiMonitor_Hochschulen_final.pdf.

Schrader, J. 2011. Struktur und Wandel der Weiterbildung. Theorie und Praxis der Erwachsenenbildung: Forschung. Bielefeld, Germany: Bertelsmann. https://doi.org/10.3278/14/1108w.

Schwarz, G. 2001. "Literacy Expanded: The Role of Media Literacy in Teacher Education." Teacher Education Quarterly 28 (2): 111-19.

Sektion Medienpädagogik. 2017. "Orientierungsrahmen Für Die Entwicklung von Curricula Für Medienpädagogische Studiengänge Und Studienanteile.” MedienPädagogik: Zeitschrift Für Theorie Und Praxis Der Medienbildung, no. December 4 (December): 1-7. https://doi. org/10.21240/mpaed/00/2017.12.04.X.

Siller, F. 2007. "Medienpädagogische Handlungskompetenzen. Problemorientierung Und Kompetenzerwerb Beim Lernen Mit Neuen Medien.” Doctoral dissertation, Mainz, Germany: Universität Mainz.

Slepkov, H. 2013. "Technology Meets Pedagogy Acquiring a Vision of Why Using Technology Makes a Difference." International Journal of Humanities and Social Science 3 (8): 120-31.

Society for Information Technology and Teacher Education [SITE], and Association for the Advancement of Computing in Education [AACE]. 2019. "SITE. About." 2019. http://site.aace. org/about/.

Spanhel, D. 1997. "Anforderungen an Die Lehrerausbildung Auf Der Basis von Erfahrungen in Modellversuchen Zur Medienerziehung." Unpublished manuscript. Nürnberg, Germany.

Spanhel, D. 2001. "Medienpädagogische Professionalität Als Integraler Bestandteil Der Lehrerprofessionalität." In Medien Machen Schule, edited by B. Herzig, 267-94. Bad Heilbrunn, Germany: Klinkhardt.

Spanhel, D. 2017. "Medienpädagogische Kompetenz Als Grundqualifikation in Pädagogischen Berufen.” MedienPädagogik, MedienPäd. Retro: Jahrbuch Medienpädagogik 2(2001), 13-26. 
State Educational Technology Directors Association [SETDA]. 2019. "Digital Instructional Materials Acquisition Policies for States." Interactive map. February 2019. https://dmaps.setda. org/?fwp_gep=gep-digital-statutes-bool.

Stiftung Akkreditierungsrat. n.d. "Stiftung Akkreditierungsrat." n.d. https://akkreditierungsrat.de/de/stiftung-akkreditierungsrat/akkreditierungsrat/ akkreditierungsrat.

Texas Education Agency [TEA]. 2019. "Approved Educator Standards.” https://tea.texas.gov/ texas_educators/preparation_and_continuing_education/approved_educator_standards/.

Texas State Board for Educator Certification. 2016. "Technology Applications EC-12 and Computer Science 8-12 Standards.” https://tea.texas.gov/WorkArea/ linkit.aspx?LinkIdentifier=id\&ItemID=51539612985\&libID=51539612985.

Tiede, J., and S. Grafe. 2016. “Media Pedagogy in German and U.S. Teacher Education.” Comunicar 24 (49): 19-28. https://doi.org/10.3916/C49-2016-02.

Tiede, J., S. Grafe, and R. Hobbs. 2015. "Pedagogical Media Competencies of Preservice Teachers in Germany and the United States: A Comparative Analysis of Theory and Practice." Peabody Journal of Education 90 (4): 533-45. https://doi.org/10.1080/0161956X.2015.1068083.

Tondeur, J., K. Aesaert, B. Pynoo, J. van Braak, N. Fraeyman, and O. Erstad. 2017. “Developing a Validated Instrument to Measure Preservice Teachers' ICT Competencies: Meeting the Demands of the 21st Century." British Journal of Educational Technology 48 (2): 462-72. https://doi.org/10.1111/bjet.12380.

Torres, M., and M. Mercado. 2006. "The Need for Critical Media Literacy In Teacher Education Core Curricula." Educational Studies: Journal of the American Educational Studies Association 39 (3): 260-82. https://doi.org/10.1207/s15326993es3903_5.

Tulodziecki, G. 2012. "Medienpädagogische Kompetenz und Standards in der Lehrerbildung." In Jahrbuch Medienpädagogik 9, edited by R. Schulz-Zander, B. Eickelmann, H. Moser, H. Niesyto, and P. Grell, 271-97. Wiesbaden, Germany: VS Verlag für Sozialwissenschaften. https://doi.org/10.1007/978-3-531-94219-3_13.

Tulodziecki, G. 2016. "Konkurrenz Oder Kooperation? Zur Entwicklung Des Verhältnisses von Medienbildung Und Informatischer Bildung." MedienPädagogik: Zeitschrift Für Theorie Und Praxis Der Medienbildung 25 (October 25): 7-25. https://doi.org/10.21240/ mpaed/25/2016.10.25.X.

Tulodziecki, G., and S. Grafe. 2019. "Media Competence." In The International Encyclopedia of Media Literacy, edited by R. Hobbs and P. Mihailidis, 1-14. Hoboken, NJ: Wiley-Blackwell. https://doi.org/10.1002/9781118978238.ieml0113.

Tulodziecki, G., and B. Herzig. 2002. Computer \& Internet im Unterricht. Medienpädagogische Grundlagen und Beispiele. Studium kompakt Neue Medien, Lernen. Berlin, Germany: Cornelsen Scriptor.

Tulodziecki, G., B. Herzig, and S. Grafe. 2010. Medienbildung in Schule und Unterricht: Grundlagen und Beispiele. UTB Erziehungswissenschaft, Schulpädagogik, allgemeine Didaktik 3414. Bad Heilbrunn, Germany: Klinkhardt. 
U.S. Department of Education. 2017a. "President's FY 2018 Budget Request for the U.S. Department of Education.” 2017. https://www2.ed.gov/about/overview/budget/budget18/index. html.

U.S. Department of Education. 2017b. "The Federal Role in Education." 2017. Retrieved from https://www2.ed.gov/about/overview/fed/role.html.

U.S. Department of Education, Office of Educational Technology. 2016. "Education Technology and Teacher Preparation Brief." Washington, D.C. https://tech.ed.gov/files/2016/12/EdTech-in-Teacher-Preparation-Brief.pdf.

U.S. Department of Education, Office of Educational Technology. 2017. "Reimagining the Role of Technology in Education: 2017 National Education Technology Plan Update." Washington, D.C. https://tech.ed.gov/files/2017/01/NETP17.pdf.

Utah Education Network [uen]. n.d. "Educational Technology Endorsement Program (ETEP)." https://www.uen.org/development/etep/.

Watson, J., A. Murin, and L. Pape. 2014. "Teaching Online Across State Lines. Keeping Pace with K-12 Digital Learning.” July 2014 Policy brief. Evergreen Education Group. https://files.eric. ed.gov/fulltext/ED558144.pdf.

Weinert, F. E. 1999. Concepts of Competence. München, Germany: Max-Planck-Institut für Psychologische Forschung.

Wetzel, K., R. R. Buss, T. Foulger, and L. Lindsey. 2014. "Infusing Educational Technology in Teaching Methods Courses: Successes and Dilemmas." Journal of Digital Learning in Teacher Education 30 (3): 89-103. https://doi.org/10.1080/21532974.2014.891877.

Wiseman, D. L. 2012. "The Intersection of Policy, Reform, and Teacher Education." Journal of Teacher Education 63 (2): 87-91. https://doi.org/10.1177/0022487111429128.

Zlatkin-Troitschanskaia, O., H. A. Pant, M. Toepper, C. Lautenbach, and D. Molerov. 2017. "Valid Competency Assessment in Higher Education: Framework, Results, and Further Perspectives of the German Research Program KoKoHs." AERA Open, January-March 20173 (1): 1-12. https://doi.org/10.1177/2332858416686739. 